MEASUREMENTS OF HEAT AND MASS FLOW FROM THERMAL AREAS

IN LASSEN VOLCANIC NATIONAL PARK, CALIFORNIA, 1984-93

Michael L. Sorey and Elizabeth M. Colvard

U.S. GEOLOGICAL SURVEY

Water Resources Investigations Report 94-4180-A

Menlo Park, California

1994 


\section{U.S. DEPARTMENT OF THE INTERIOR \\ BRUCE BABBITT, Secretary \\ U.S. GEOLOGICAL SURVEY \\ Gordon P. Eaton, Director}

For additional information

Copies of this report can be write to:

Michael L. Sorey

U.S. Geological Survey

purchased from :

345 Middlefield Road

Menlo Park, California 94025

U.S. Geological Survey

Earth Science Information Center

Open-File Reports Section

Box 25286, MS 517

Denver Federal Center

Denver, Colorado 80225 


\section{CONTENTS}

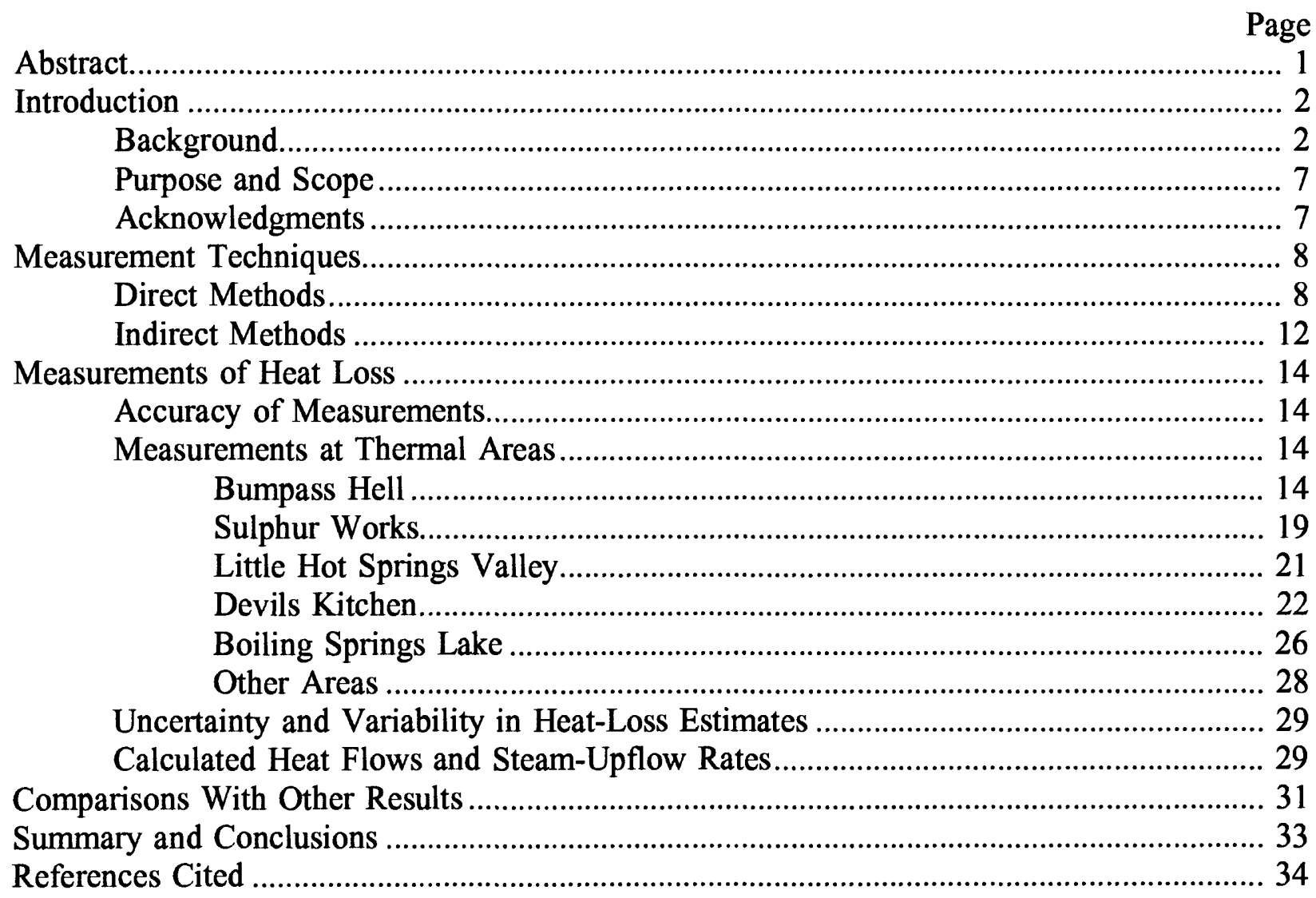




\section{ILLUSTRATIONS}

Figure 1. Map showing physiographic provinces in northern California (modified

Page from Fenneman, 1928), location of Lassen Volcanic National Park (LVNP), and Lassen Known Geothermal Resources Area (KGRA), and simplified geologic map of the Lassen region

Figure 2. Map showing areas of thermal-fluid discharge and major streams in the Lassen region

Figure 3. Diagram showing conceptual model of the Lassen hydrothermal system (from Sorey and Ingebritsen, 1984)

Figure 4. Map showing steam-heated thermal areas near the central vent area of the Lassen volcanic center. 9

\section{TABLES}

Table 1. Typical concentrations of selected ions in thermal waters from Lassen Volcanic National Park and Lassen Known Geothermal Resources Area (KGRA).

Table 2. Heat loss from different types of features at the Bumpass Hell thermal area (upper and lower basins), Lassen Volcanic National Park

Table 3. Range of measurements in superheated fumaroles at various thermal areas in Lassen Volcanic National Park over the period 1987-93

Table 4. Average values of heat loss by advection in streams $\left(\mathrm{H}_{\mathrm{ADV}}\right)$ and heat input to thermal area corresponding to the outflow of dissolved sulfate $\left(\mathrm{H}_{\mathrm{s}}\right)$, based on measurements over the period 1984-93, Lassen Volcanic National Park

Table 5. Heat loss from different types of features at the Sulphur Works thermal area, Lassen Volcanic National Park

Table 6. Heat loss from different types of features at the Little Hot Springs Valley thermal area, Lassen Volcanic National Park

Table 7. Heat loss from different types of features at the Devils Kitchen thermal area, Lassen Volcanic National Park

Table 8. Summary of total heat loss, heat flow, and inferred rate of steam upflow at thermal areas in Lassen Volcanic National Park

Table 9. Total heat loss and heat flow for steam-heated thermal areas at Lassen Volcanic National Park, summit regions of other Cascade volcanoes, and Ketetahi Hot Springs in New Zealand. 


\section{CONVERSION FACTORS}

Conversion factors for terms used in this report are listed below:

\section{Multiply}

meter (m)

kilogram $(\mathrm{kg})$

kilojoule (kJ)

megawatt (MW)

watt per square meter $\left(\mathrm{W} / \mathrm{m}^{2}\right)$

milligram per liter $(\mathrm{mg} / \mathrm{L})$

liter per second $(\mathrm{L} / \mathrm{s})$

grams per second $(\mathrm{g} / \mathrm{s})$

meters per second $(\mathrm{m} / \mathrm{s})$

pascals $(\mathrm{Pa})$ $\underline{\text { By }}$

\subsection{1}

0.4536

238.9

238,900

23.89

$6.243 \times 10^{-5}$

0.03532

$4.536 \times 10^{-4}$

3.281

$1.4508 \times 10^{-5}$
To Obtain

feet (ft)

pound (lb)

calorie (cal)

calories per second (cal/s)

heat-flow units (hfu)

$\left(1 \mathrm{hfu}=1 \mu \mathrm{cal} / \mathrm{cm}^{2} / \mathrm{s}\right)$ pounds per cubic foot $\left(\mathrm{lb} / \mathrm{ft}^{3}\right)$ cubic feet per second $\left(\mathrm{ft}^{3} / \mathrm{s}\right)$ pounds per second $(\mathrm{lb} / \mathrm{s})$ feet per second ( $\mathrm{ft} / \mathrm{s})$ pounds per square inch $\left(\mathrm{lb} / \mathrm{in}^{2}\right)$

For conversion of degrees Celsius $\left({ }^{\circ} \mathrm{C}\right)$ to degrees Fahrenheit $\left({ }^{\circ} \mathrm{F}\right)$, use the formula:

$$
{ }^{\circ} \mathrm{F}=1.8^{\circ} \mathrm{C}+32 \text {. }
$$




\title{
MEASUREMENTS OF HEAT AND MASS FLOW FROM THERMAL AREAS IN LASSEN VOLCANIC NATIONAL PARK, CALIFORNIA, 1984-93
}

Michael L. Sorey and Elizabeth M. Colvard

\begin{abstract}
Rates of heat loss from eight steam-heated thermal areas and one conductively heated thermal area in Lassen Volcanic National Park have been determined from measurements made during the period 1984-93. Total heat discharge at the steam-heated areas is assumed proportional to the rate of steam upflow from underlying reservoirs. The dominant mode of heat loss differs among the areas studied; at Bumpass Hell and Boiling Springs Lake evaporation from water surfaces dominates, whereas at Devils Kitchen and Little Hot Springs Valley most of the heat is lost by advection in streams. Heat loss from fumaroles, which discharge at temperatures of $93-157^{\circ} \mathrm{C}$ depending on the area, accounts for less than 30 percent of the total heat loss for all but the smallest thermal areas. Estimates of total heat loss from the eight steam-heated areas range from about 30 megawatts at Bumpass Hell and Boiling Springs Lake to less than 2 megawatts at Terminal Geyser, Pilot Pinnacle and Lassen Peak, and total about 120 megawatts. The corresponding rate of steam upflow required to supply this total heat loss is approximately 40 kilograms per second, with about half providing heat input to the five thermal areas situated on the flanks of Lassen Peak and the remainder supplying heat to thermal areas situated to the southeast of Lassen Peak along or near Hot Springs Creek. For the most part, heat-loss measurements were made during late summer and fall when streamflows were relatively low. At each thermal area, rates of streamflow and advective heat loss are greatest in the spring and early summer, reflecting depletion of stored heat by infiltrating cold water. Such seasonal variations, along with variations due to errors in our heat-loss determinations, result in uncertainties of approximately \pm 20 percent in our estimates of total heat loss and steam upflow at all the Park's thermal areas.
\end{abstract}




\section{INTRODUCTION}

\section{Background}

Lassen Volcanic National Park (LVNP), located in northeastern California at the southern end of the Cascade Range, encompasses a $428 \mathrm{~km}^{2}$ region of Cenozoic volcanic rocks and surficial hydrothermal activity (figs. 1 and 2). The Cascade Range in the Lassen region is a broad ridge of late Pliocene and Quaternary volcanic rocks primarily of basaltic to andesitic composition. Superimposed on the regional mafic volcanism are a few long-lived silicic volcanic centers that have erupted products ranging from basaltic andesite to rhyolite. Five such centers younger than about 3 million years $(\mathrm{Ma})$ have been recognized in the Lassen region; the youngest is termed the Lassen volcanic center and hosts active silicic volcanism and a well-developed hydrothermal system (Clynne and Muffler, 1989; Muffler and others, 1982). The Lassen volcanic center includes Lassen Peak, a dome emplaced at about 20 thousand years (ka) and Chaos Crags, a dome complex emplaced at $1 \mathrm{ka}$ (Clynne and Muffler, 1989). The most recent eruptions in the region occurred 1914-1917 on Lassen Peak.

Thermal waters discharge in the southern part of the Park and in the Lassen Known Geothermal Resources Area (KGRA) south of the Park. Thermal areas inside the Park are steamheated, that is, they have developed above zones of steam upflow. In such areas, steam may discharge directly as fumaroles or condense to supply heat and gas to the shallow ground-water system. Steam-heated ground waters are typically acidic and contain relatively low concentrations of most dissolved constituents (White and others, 1971). Concentrations of selected ions in steam-heated thermal waters inside the Park and in waters from Morgan and Growler Hot Springs south of the Park are compared in table 1. The latter waters contain high concentrations of chloride and other conservative ions, as does water produced from the geothermal well at Terminal Geyser (location shown in fig. 2). Conceptual models discussed by Muffler and others (1982), Sorey and Ingebritsen (1984), and Ingebritsen and Sorey $(1985,1988)$ describe the geothermal system at Lassen as being liquid-dominated with a parasitic vapordominated zone. In this model, areas of steam discharge situated at relatively high elevations in the Park and areas of high-chloride liquid discharge situated at relatively low elevations in the KGRA are fed by an upflow of high-enthalpy two-phase fluid beneath the Park (fig. 3). The available evidence indicates that liquid flows laterally away from the principal upflow area along permeable pathways toward springs at lower elevation along Mill Creek and the Feather River, whereas steam rises through a central vapor-dominated zone toward discharge areas at relatively high elevation inside the Park.

Fluid and gas samples from hot springs and steam vents in the Lassen region were first collected in the late 1970's (Muffler and others 1982; Truesdell and others, 1983; and Thompson, 1985). Periodic monitoring of the rate and composition of thermal-fluid discharge from thermal areas in LVNP and the adjacent KGRA began in 1983. A preliminary report described results of monitoring the discharge of high-chloride springs in the KGRA and sulfate outflow from two areas inside the Park during 1983-1985 (Sorey, 1986). Further measurements of thermal water input to streams draining the Lassen region were reported by Paulson and Ingebritsen (1991). Analyses and interpretations of gas compositions and water isotopes from fumarolic and hotspring samples collected during 1975-1980 were presented by Muffler and others (1982), Janik and others (1983), and Truesdell and others (1983). Annual sampling of thermal features for 
EXPLANATION

Rocks extruded from:

a Lassen Volcanic Center

b Dittmar Volcanic Center

C. Maidu Volcanic Center

d. Sources outside

mapped region

Vent for Holocene

volcanism

Central vent area for

major Quaternary

volcanic center
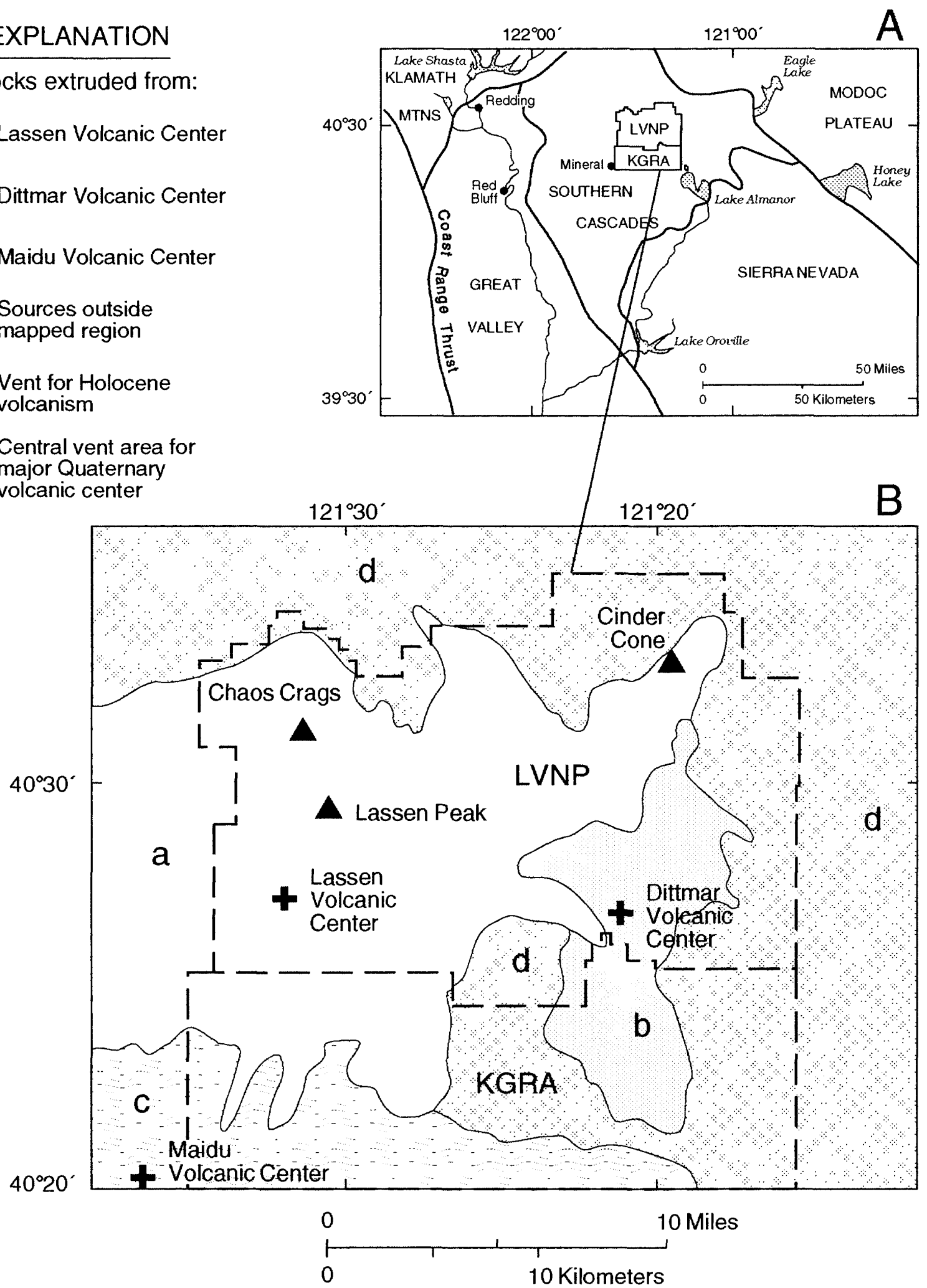

Figure 1. Maps showing A) physiographic provinces in northern California (modified from Fenneman, 1946), location of Lassen Volcanic National Park (LVNP) and Lassen Known Geothermal Resources Area (KGRA), and B) simplified geologic map of the Lassen region. 


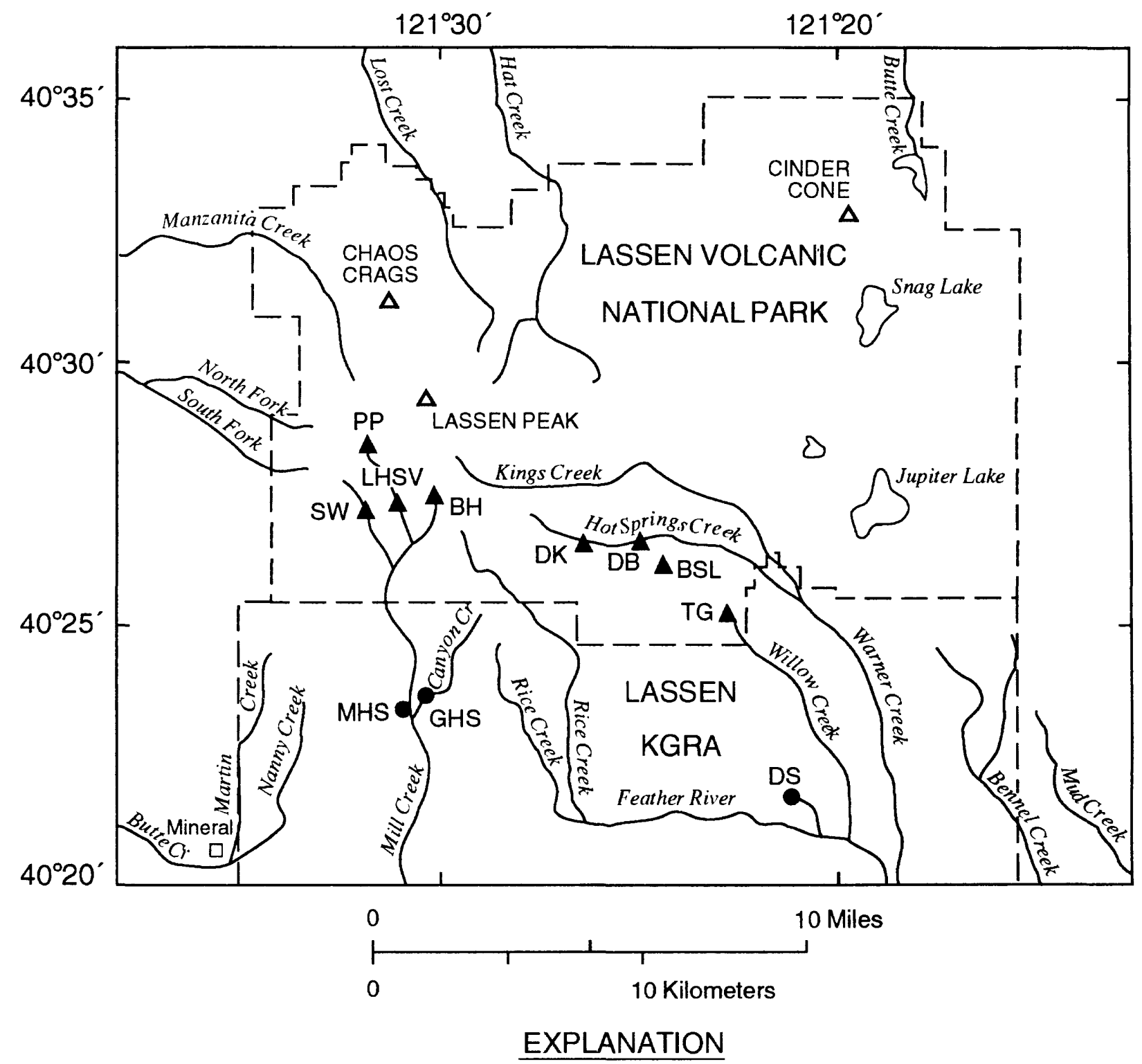

$\Delta$ Area of recent eruptive activity

A Principal steam-heated thermal area

$\begin{array}{llll}\text { BH } & \text { Bumpass Hell } & \text { PP } & \text { Pilot Pinnacle } \\ \text { BSL } & \text { Boiling Springs Lake } & \text { SW } & \text { Sulphur Works } \\ \text { DK } & \text { Devils Kitchen } & \text { TG } & \text { Terminal Geyser } \\ \text { LHSV } & \text { Little Hot Springs Valley } & \text { DB } & \text { Drakesbad (conductively heated) }\end{array}$

- Area of neutral-pH thermal springs

DS Domingo Springs

MHS Morgan Hot Spring

GHS Growler Hot Spring

Figure 2. Map showing areas of thermal fluid discharge and major streams in the Lassen region. A small steam-heated thermal area (not shown) also exists on the northwest side of Lassen Peak. 
Table 1.--Typical concentrations of selected ions in thermal waters from Lassen Volcanic National Park (LVNP) and Lassen Known Geothermal Resources Area (KGRA)

[Data from Thompson (1985); --, no data; ${ }^{\circ} \mathrm{C}$, degrees Celsius; $\mathrm{mg} / \mathrm{L}$, milligrams per liter]

Location

Temperature $\mathrm{pH}$

$\left({ }^{\circ} \mathrm{C}\right)$

$\mathrm{SO}_{4}$

$\mathrm{Cl}$

B

As

$(\mathrm{mg} / \mathrm{L})$

$(\mathrm{mg} / \mathrm{L})$

$(\mathrm{mg} / \mathrm{L}) \quad(\mathrm{mg} / \mathrm{L})$

Inside LVNP:

Bumpass Hell

93

2.0

458

$<1$

6.5

140

3

Drakesbad

65

$-$

81

2,180

62

9.9

In Lassen KGRA:

\begin{tabular}{lrrrrrr} 
Morgan Hot Springs & 94 & 7.2 & 110 & 2,250 & 67 & 10.4 \\
Growler Hot Springs & 94 & 8.0 & 90 & 2,430 & 71 & 12.7 \\
\hline
\end{tabular}

${ }^{1}$ Temperature of sample collected at wellhead. Subsurface temperature of production zone $=$ $176^{\circ} \mathrm{C}$ (Beall, 1981). 


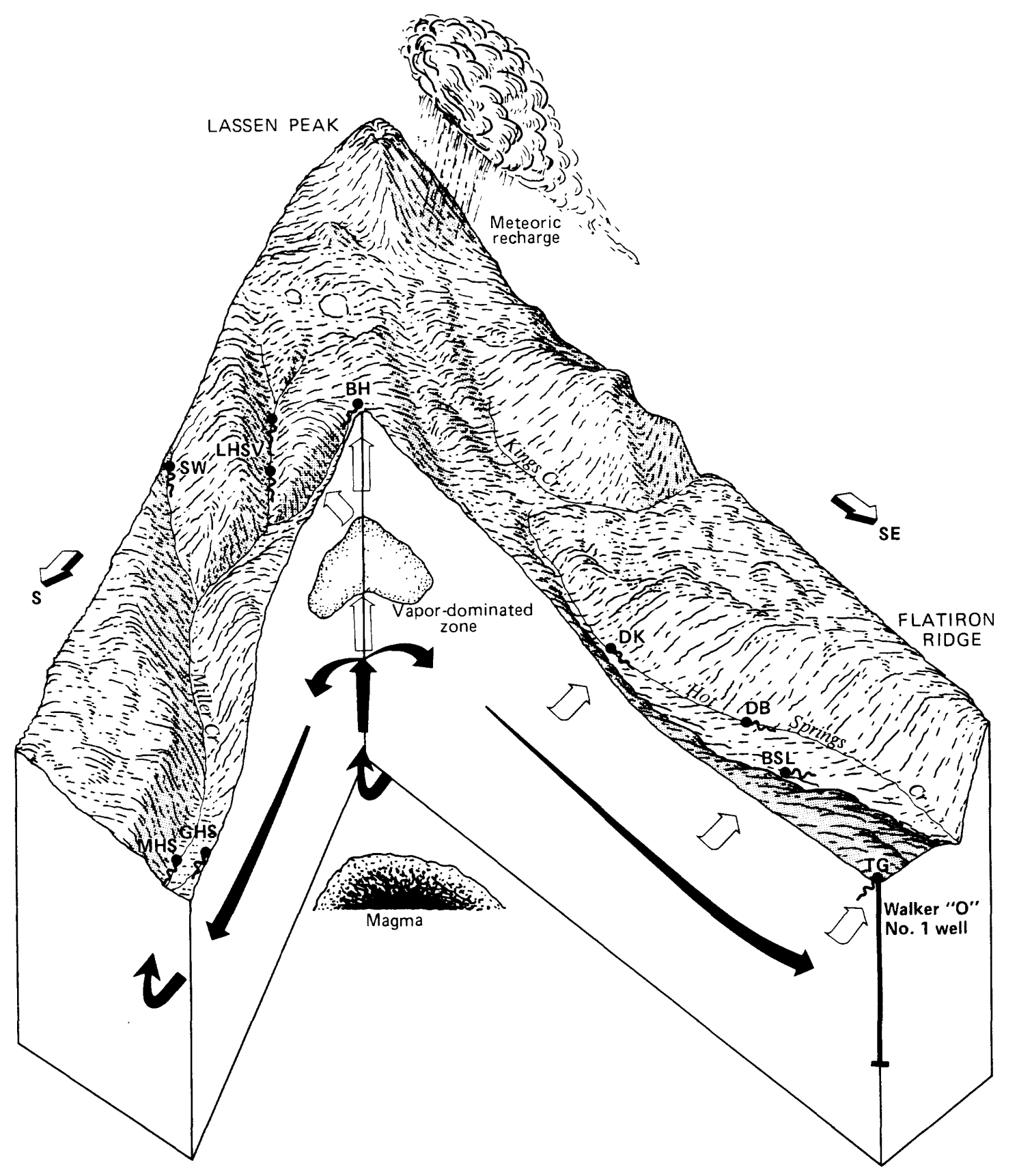

Figure 3. Diagram showing conceptual model of the Lassen hydrothermal system (from Sorey and Ingebritsen, 1984). Zones of hot-water and steam flow shown by solid and open arrows, respectively. Vertical exaggeration is approximately five times the horizontal dimension (see figure 2 for explanation of abbreviations used). 
chemical and isotopic compositions has continued since 1983 (C. Janik, U.S. Geological Survey, written communication, 1994).

\section{Purpose and Scope}

This report describes methods used to determine rates of heat loss from different types of features at thermal areas in LVNP and presents the results of such measurements made during 1984-93. These features include fumaroles, water surfaces, bare ground, and streams. These heat-loss data are compared with heat-loss estimates made for several of the Lassen thermal areas by Friedman and Frank (1978) using Landsat-1 MSS images of October 1972, and with heat- loss values reported for other volcanoes. From our estimates of the total heat loss at each steamheated thermal area, rates of steam upflow from underlying geothermal reservoirs required to supply this heat loss are calculated.

\section{Acknowledgments}

The authors are indebted to Barbara Simpson, then of the New Zealand Geological Survey, for establishment of the general methodology for making direct measurements of heat flow from the Lassen thermal areas and for making the initial heat-loss measurements at Lassen in 1986. The assistance of Alan Denniston and Elizabeth Knight of the National Park Service and Michael Friebel and Lee Price of the U.S. Geological Survey in our field investigations is also gratefully acknowledged. 


\section{MEASUREMENT TECHNIQUES}

Nine principal areas of thermal-fluid discharge occur within the southwestern part of the Park (fig. 2), at elevations ranging from 1,730 to $2,680 \mathrm{~m}$. Fluid discharge at each area consists of steam, steam condensate, steam-heated ground water, or conductively heated ground water. During our study, fumarolic temperatures ranged from $93^{\circ} \mathrm{C}$, the boiling-point for pure water at an elevation near $2,500 \mathrm{~m}$, to $157^{\circ} \mathrm{C}$. A temperature of $159^{\circ} \mathrm{C}$, measured at Bumpass Hell in 1979 may be the highest temperature ever recorded in a geothermal (non-volcanic) fumarole (Muffler and others, 1982). The thermal areas can be geographically grouped into a set of five areas located around the flanks of Lassen Peak and a set of four areas located along the drainage of Hot Springs Creek and Willow Creek (fig. 2). Areas in set 1, which occur in or around the central vent area for the Lassen volcanic center (fig. 4), include Bumpass Hell, Little Hot Springs Valley, Sulphur Works, Pilot Pinnacle, and Lassen Peak itself. Areas in set 2, which occur along easterly and southeasterly trending fault zones and are underlain by a region of low electrical resistivity (Christopherson and Pringle, 1981; Sorey and Ingebritsen, 1984), include Devils Kitchen, Drakesbad, Boiling Springs Lake, and Terminal Geyser.

Heat is discharged from the Lassen thermal areas by various modes, including (1) conduction, diffusion, and radiation from bare ground, (2) evaporation and radiation from water surfaces, and (3) advection from fumaroles and hot springs. Direct methods were used to measure or estimate heat loss. Direct methods involved calculations based on measurements of parameters such as atmospheric pressure and wind speed, temperatures of streams, pools and fumaroles, and flow rates of streams and fumaroles. Rates of steam upflow required to supply the total heat loss at each area were estimated from energy-balance computations for assumed values of steam enthalpy. A more indirect method was also used to estimate steam upflow at several areas where measurements of sulfate outflow in streams could be made. This method assumes that a measured flux of dissolved sulfate can be related to fluxes of $\mathrm{H}_{2} \mathrm{~S}$ and steam originating in an underlying vapor-dominated zone.

\section{Direct Methods}

Total heat flow $\left(\mathrm{H}_{\mathrm{TOT}}\right)$ at each thermal area is given by:

$$
\mathrm{H}_{\mathrm{TOT}}=\mathrm{H}_{\mathrm{FUM}}+\mathrm{H}_{\mathrm{ADV}}+\mathrm{H}_{\mathrm{EVAP}}+\mathrm{H}_{\mathrm{RAD}}+\mathrm{H}_{\mathrm{COND}}+\mathrm{H}_{\mathrm{GR}} \text {, }
$$

where $\mathrm{H}_{\mathrm{FUM}}$ is differential advective heat loss in fumaroles;

$\mathrm{H}_{\mathrm{ADV}}$ is advective heat loss in streams and springs;

$\mathrm{H}_{\text {EVAP }}$ is evaporative heat loss from water surfaces;

$H_{R A D}$ is radiative heat loss from water surfaces;

$\mathrm{H}_{\mathrm{COND}}$ is conductive and diffusive heat loss from water surfaces; and

$\mathrm{H}_{\mathrm{GR}}$ is heat flow from bare ground by convection, evaporation, and conduction.

Equations for evaluating each of these terms were developed in part from similar expressions described by Dawson (1964) and Dawson and Dickinson (1970). Each of these heatloss terms is computed in units of megawatts $(\mathrm{MW})$, or $10^{6}$ joules per second. 


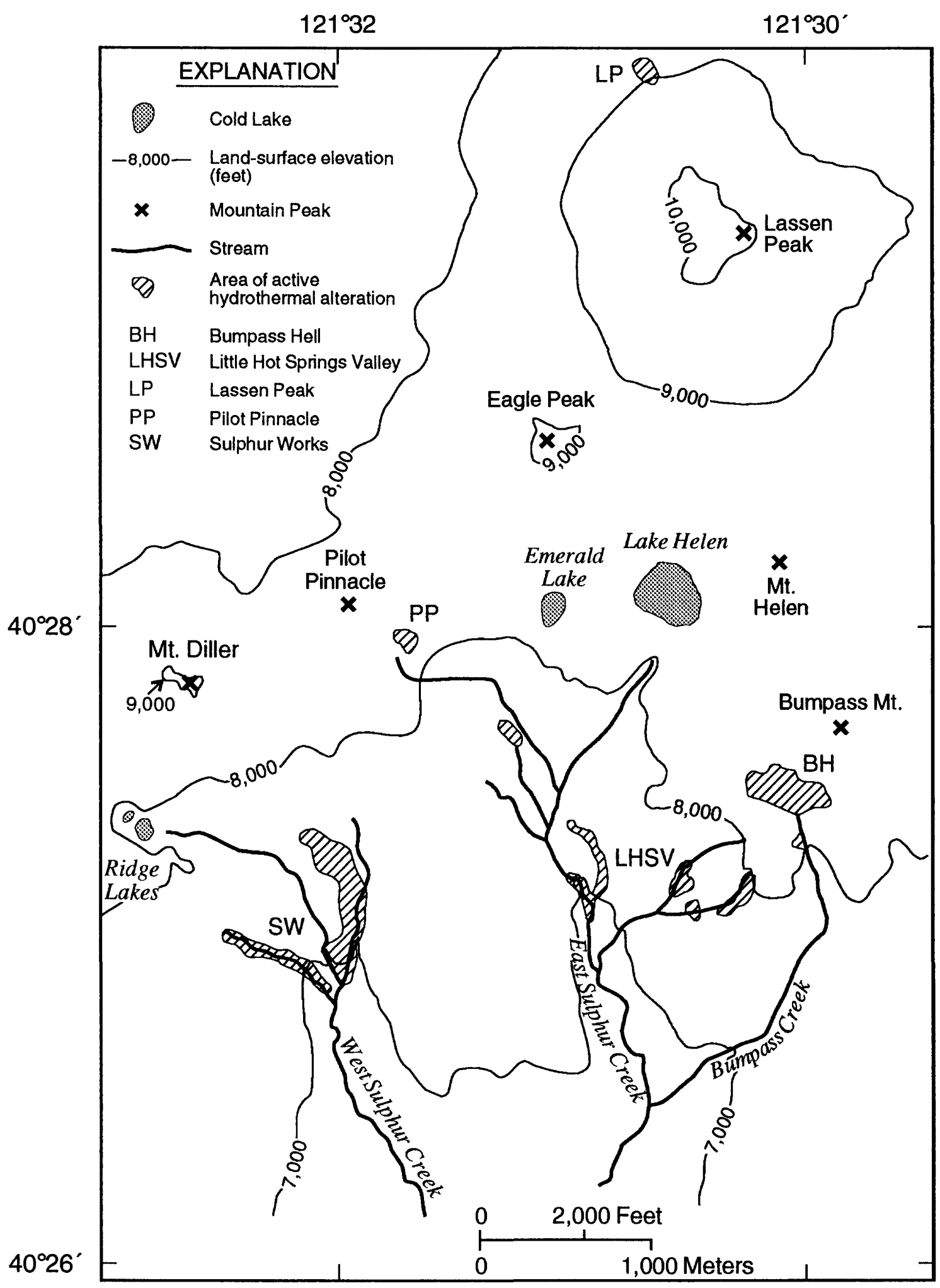

Figure 4. Map showing steam-heated thermal areas near the central vent area of the Lassen volcanic center. 
Advective heat loss from fumaroles is the product of the mass discharge and steam enthalpy:

$$
\mathrm{H}_{\mathrm{FUM}}=0.001 \mathrm{M}_{\mathrm{s}} \mathrm{h}_{\mathrm{s}} \text {, }
$$

where $M_{s}$ is the mass discharge of steam in $\mathrm{kg} / \mathrm{s}$ and $h_{s}$ is the enthalpy of steam exiting the vent in $\mathrm{kJ} / \mathrm{kg}$. Values of $\mathrm{M}_{\mathrm{s}}$ were calculated as the product of steam density times steam velocity. Steam density was evaluated at the measured vent temperature, assuming a steam pressure equal to local atmospheric pressure. Steam velocity was measured with either an anemometer or a pitot tube and pressure meter. The pitot-tube measurements were more accurate than the anemometer measurements for vents with areas less than about $60 \mathrm{~cm}^{2}$. For vent areas less than about 30 $\mathrm{cm}^{2}$, the anemometer gives a velocity reading that is low by a factor of 2-3. Consequently, anemometer measurements made before 1989, when the pitot tube was first used, were corrected upward to be consistent with the pitot-tube values. As with density, values of steam enthalpy were evaluated for the measured vent temperature and local atmospheric pressure.

Differential advective heat loss from hot springs and streams is calculated relative to an ambient reference temperature as:

$$
\mathbf{H}_{\mathrm{ADV}}=0.001 \mathrm{M}_{\mathrm{w}}\left(\mathrm{h}_{\mathrm{w}}-\mathrm{h}_{0}\right) \text {, }
$$

where $M_{w}$ is the mass flow of heated water in $\mathrm{kg} / \mathrm{s}, \mathrm{h}_{\mathrm{w}}$ is the enthalpy of the discharging water in $\mathrm{kJ} / \mathrm{kg}$, and $h_{0}$ is the enthalpy of water at a reference temperature in $\mathrm{kJ} / \mathrm{kg}$. Reference temperatures were either assumed to be $4^{\circ} \mathrm{C}$ or were set at the temperature of the stream flowing into the thermal area.

Evaporation from calm water surfaces is driven by a vapor-pressure gradient and can be calculated using a semi-empirical formula adapted from the International Critical Tables (Washburn, 1929):

$$
H_{E V A P}=0.001 A h_{f_{g}}(0.0065+0.0029 W)\left(p_{s}-p_{d}\right) / p_{1} \text {, }
$$

where $A$ is the area of the water surface $\left(\mathrm{m}^{2}\right)$;

$\mathrm{h}_{\mathrm{fg}}$ is the enthalpy of phase change at the temperature of the water surface $(\mathrm{kJ} / \mathrm{kg})$;

$\mathrm{W}$ is wind speed $(\mathrm{m} / \mathrm{s})$;

$\mathrm{p}_{\mathrm{s}}$ is the saturation water vapor pressure at the temperature of the water surface $(\mathrm{Pa})$;

$\mathrm{p}_{\mathrm{d}}$ is the atmospheric vapor pressure $(\mathrm{Pa})$; and

$\mathrm{p}_{1}$ is the atmospheric pressure $(\mathrm{Pa})$.

Solution of this equation requires water-temperature data plus meteorological information which can either be measured on site or inferred from surrounding meteorological stations. If the water surface is vigorously boiling, evaporative heat loss can be significantly enhanced. 
Radiative heat loss is controlled by the absolute temperature $\mathrm{T}$ and emissivity $\varepsilon$ of the radiating surface. For water $\varepsilon=0.955$ and for bare soil $\varepsilon=0.88-0.99$. Differential radiative heat loss is calculated relative to a reference temperature $\mathrm{T}_{0}$ of $0^{\circ} \mathrm{C}\left(273.15^{\circ} \mathrm{K}\right)$ as:

$$
\mathrm{H}_{\mathrm{RAD}}=0.001 \mathrm{A \varepsilon \sigma}\left(\mathrm{T}^{4}-\mathrm{T}_{0}^{4}\right) \text {, }
$$

where $A$ is the area of the radiating surface, in $\mathrm{m}^{2}$, and $\sigma$ is the Stefan-Boltzmann constant (5.679 x $\left.10^{-11} \mathrm{MW} / \mathrm{m}^{2} /{ }^{\circ} \mathrm{K}\right)$.

Heat loss from a water surface by conduction and molecular diffusion is driven by the temperature gradient just above the water. It is usually a relatively minor component of the total heat loss and can be related to the evaporative heat loss by the Bowen Ratio R (Sutton, 1953):

$$
R=H_{C O N D} / H_{E V A P}=6.1 \times 10^{-7} p_{1}\left(T_{w}-T_{a}\right) /\left(p_{s}-p_{a}\right),
$$

where $T_{w}$ is the water surface temperature in ${ }^{\circ} \mathrm{C}, T_{a}$ is the air temperature, and $p_{a}$ is the atmospheric saturation vapor pressure $(\mathrm{Pa})$.

Heat flow from bare ground can occur by conduction, evaporation, and convection. In steam-heated thermal areas, shallow convection of hot water or steam is commonly the dominant mode of heat transfer. Dawson (1964) developed an empirical technique for determining total ground surface heat flow. The method is based on measurements of soil temperature at a depth of $15 \mathrm{~cm}$ which were calibrated against a portable calorimeter for conditions at the Wairakei geothermal area in New Zealand. This yields the relation:

$$
\mathrm{H}_{\mathrm{GR}}=5.19 \times 10^{-12} \mathrm{AT}_{15}^{4} \text {, }
$$

where $\mathrm{A}$ is the area of bare ground, in $\mathrm{m}^{2}, \mathrm{~T}_{15}$ is the ground temperature at a depth of $15 \mathrm{~cm}$, in ${ }^{\circ} \mathrm{C}$, and the constant has the units of $\mathrm{MW} / \mathrm{m}^{2} /\left({ }^{\circ} \mathrm{C}\right)^{4}$. Dawson's equation was applied to thermal areas at Lassen using a revised constant of $6.7 \times 10^{-12}$ to account for the change in boiling point with elevation.

Limited measurements of advective heat loss at Lassen were begun in 1983; the first detailed assessment of heat flow at the Lassen thermal areas was made in 1986. Additional measurements of heat loss by the principal modes at four areas have been made annually since 1986. The general approach taken to assess heat flow by direct techniques was the same for each area. Climatic data were obtained from the meteorological station in Redding, California, and from on-site measurements with a portable barometer, sling psychrometer, and digital thermometer. Surface temperatures were measured at each thermal pool, unless ground conditions were too dangerous, and pool areas were either estimated or calculated from stadia and compass readings. Liquid outflows from pools, springs, and streams were measured with a pygmy current meter or estimated. Limited measurements of ground temperature at a depth of $15 \mathrm{~cm}$ were made in representative parts of each thermal area visited. 
During site visits in 1986, rates of steam flow from fumaroles were not measured; instead, steam vents were inventoried and assigned an index of relative output based on temperature measurements and visual observation of steam condensate clouds. This work was aided by descriptive inventories and vent temperature measurements made during the 1976-79 period by L.J.P. Muffler (Muffler and others, 1983; L.J.P. Muffler, written communication, 1986). Measurements of steam velocity made in many of these vents in subsequent years using either an anemometer or a pitot tube and pressure transducer formed the basis for estimating mass and heat flows from fumaroles. For other steam-heated features, such as frying pans and drowned fumaroles, heat-flow estimates were assigned on the basis of evaporative heat loss from a vigorously boiling water surface of equivalent surface area (frying pans) or steam flow measurements in nearby fumaroles (drowned fumaroles).

Calculated values of heat flow from bare ground (eq. 7) depend on values chosen for the average temperature at $15 \mathrm{~cm}$ depth and the area of anomalously warm ground. Detailed groundtemperature measurements were made only at Sulphur Works, where temperatures at $15 \mathrm{~cm}$ were commonly greater than $80^{\circ} \mathrm{C}$ adjacent to hot springs and fumaroles but $35^{\circ} \mathrm{C}$ or less within the remainder of the area. Limited ground-temperature measurements at Bumpass Hell, Devils Kitchen, and Little Hot Springs Valley indicate average $15 \mathrm{~cm}$ temperatures of $35-50^{\circ} \mathrm{C}$ away from the springs and fumaroles. Temperatures of 35,50 , and $80^{\circ} \mathrm{C}$ at $15 \mathrm{~cm}$ correspond to heat flows (rounded to 1 significant digit) of 10,40 , and $300 \mathrm{~W} / \mathrm{m}^{2}$, respectively.

\section{Indirect Methods}

The rate of outflow of sulfate dissolved in streams and hot springs provides an indirect measure of the rate of upflow of steam and associated $\mathrm{H}_{2} \mathrm{~S}$ from vapor-dominated zones beneath some of the Lassen thermal areas. The basis for this relation is that some or all of the advected sulfate must come from near-surface oxidation of $\mathrm{H}_{2} \mathrm{~S}$. If the ratio of $\mathrm{H}_{2} \mathrm{~S}$ to steam in the upflow is known, measurements of sulfate outflow provide rough estimates of the rate of steam upflow, as discussed by Giggenbach and Stewart (1982). Complicating factors include the possibility that sulfate is also contributed to the surface drainage from products of rock weathering, that some $\mathrm{H}_{2} \mathrm{~S}$ reacts with rocks to form pyrite and sulfur, and that $\mathrm{H}_{2} \mathrm{~S}$ gas may be discharged from fumaroles and hot pools. Comparison of steam upflow rates and corresponding heat inputs indicated by sulfate outflow measurements with those indicated by measurements of heat advected in streams and hot springs (eq. 3) may permit the influence of these complicating factors to be evaluated. The advantage of using dissolved sulfate instead of stream temperature as a measure of advected heat is that temperature changes and heat losses in the stream above the point of flow measurement do not need to be considered. Sulfate-outflow measurements made at Bumpass Hell, Sulphur Works, Little Hot Springs Valley, and Devils Kitchen are discussed below.

Sulfate outflow $\left(\mathrm{M}_{\mathrm{S}}\right)$ is calculated as the product of streamflow and average sulfate concentration. The associated heat input $\mathrm{H}_{\mathrm{S}}$ is then given by:

$$
H_{s}=0.67 M_{s} \text {, }
$$

where the constant 0.67 has the units of MW per g/s sulfate outflow. This value was obtained 
from the molar ratio of steam to $\mathrm{H}_{2} \mathrm{~S}$ in fumarolic gas sampled from Bumpass Hell, as discussed in the next section. At Little Hot Springs Valley and Devils Kitchen, $M_{S}$ in equation 8 was taken from the difference in sulfate outflow between gaging sites above and below the principal thermal area. 


\title{
MEASUREMENTS OF HEAT LOSS
}

\author{
$\underline{\text { Accuracy of Measurements }}$
}

No rigorous determination of the accuracy of our measurements and estimates of heat loss at each thermal area has been made, and it is emphasized that these estimates are based on measurements made at times of relatively low streamflow in late summer and fall. Under such conditions, approximate measures of the possible range in each heat-loss determination were derived from (1) the observed variability in quantities that were measured on many visits, for example advective heat loss in streams, and (2) estimated errors of up to \pm 50 percent for less well constrained or less frequently measured quantities such as heat losses from fumaroles and bare ground. These ranges are shown in the tables that follow as 1 standard deviation $(\sigma)$ uncertainties. An estimate of the standard deviation for total heat loss at each area was then obtained from the square-root of the sum of the squares of the estimated standard deviations for heat loss from each type of feature. This procedure weights the estimated error in total heat loss at each area toward the error associated with measurements of the dominant mode of heat loss. It also tends to reduce the estimated uncertainty for the heat loss from each area and the total loss for all the thermal areas. In contrast, the effect of seasonal variations in heat loss detected at several areas tends to increase the uncertainty in determinations of average rates of heat loss over the year.

\section{Measurements at Thermal Areas}

\section{Bumpass Hell}

The Bumpass Hell thermal area is the highest of the major thermal areas in the Park and consists of two vegetation-free basins at average elevations of $2,500 \mathrm{~m}$ and $2,460 \mathrm{~m}$, located about $3 \mathrm{~km}$ southeast of Lassen Peak (fig. 4). The upper and lower basins are separated by a distance of about $200 \mathrm{~m}$; the area of the lower basin is only about 10 percent of that of the upper basin and heat discharge from it represents an even smaller fraction of the total heat flow for the area. Thermal activity at Bumpass Hell includes superheated fumaroles, drowned fumaroles, hot pools of large surface area, and thermal-water inflow to Bumpass Creek as it drains through the upper and lower basins. Total heat loss for both basins is calculated from direct measurements to be $29 \pm 4 \mathrm{MW}$, most of which $(20 \mathrm{MW})$ is attributed to heat loss from five hot $\left(50-90^{\circ} \mathrm{C}\right)$ pools and the streams draining these pools in the upper basin (table 2). The total heat loss listed for the five pools represents an average of four measurements made over the 1986-1988 period, during which both the temperature and area of each pool remained relatively constant.

Heat loss from bare ground represents the next largest component of total heat loss. Our estimate of $\mathrm{H}_{\mathrm{GR}}(6 \pm 3 \mathrm{MW})$ is based on a total area of heated ground of $44,000 \mathrm{~m}^{2}$. This area was calculated from the area of heated ground determined by Friedman and Frank (1978) from satellite imagery, less the area of the hot pools and streams. Heat-flow values of 10,40 , and 300 $\mathrm{W} / \mathrm{m}^{2}$ over 60,20 , and 20 percent, respectively, of the area of bare ground were assumed, based on equation 7 and average ground temperatures of $35^{\circ} \mathrm{C}, 50^{\circ} \mathrm{C}$, and $80^{\circ} \mathrm{C}$, respectively. 
Table 2.--Heat loss from different types of features at the Bumpass Hell (upper and lower basins) thermal area, Lassen Volcanic National Park

[--, no data; $\mathrm{m}^{2}$, square meters; MW, megawatts $]$

\begin{tabular}{lcccc}
\hline $\begin{array}{l}{ }^{1} \text { Type of } \\
\text { Feature }\end{array}$ & $\begin{array}{c}\text { Number of } \\
\text { Features }\end{array}$ & $\begin{array}{c}{ }^{2} \text { Area } \\
\left(\mathrm{m}^{2}\right)\end{array}$ & $\begin{array}{c}{ }^{3} \text { Heat Loss } \\
(\mathrm{MW})\end{array}$ & $\begin{array}{c}{ }^{4} \text { Period of } \\
\text { Observation } \\
\text { number }\}\end{array}$ \\
\hline Fumaroles & 30 & -- & $2 \pm 1$ & $\begin{array}{c}1987-90 \\
\{5\}\end{array}$ \\
Water surfaces & 5 & 1,600 & ${ }^{5} 20 \pm 2$ & $\begin{array}{c}1986-88 \\
\{4\}\end{array}$ \\
Bare ground & -- & 44,000 & ${ }^{6} 6 \pm 3$ & $\begin{array}{c}1986 \\
\{1\}\end{array}$ \\
Streamflow & 1 & -- & $70.53 \pm 0.33$ & $1984-93$ \\
& & & & $\{17\}$ \\
\hline
\end{tabular}

${ }^{1}$ Fumaroles include steam vents, drowned steam vents, and frying pans; Water surfaces include 5 small lakes containing thermal water and Bumpass Creek; Streamflow refers to Bumpass Creek at a flume installed in 1984 at a site $30 \mathrm{~m}$ below the boardwalk.

2 Total area of heated ground equals the anomalously warm area determined from infrared photos analyzed by Friedman and Frank (1978). Area of water surfaces determined from visual inspections and stadia measurements averaged over four sets of observations.

${ }^{3}$ Calculated or estimated $1 \sigma$ uncertainties shown with \pm . Uncertainty for total heat loss calculated from the square root of the sum of squares of $\sigma$ 's for each type of feature.

${ }^{4}$ Years during which one or more visits were made; \{number\} is the number of observations of heat loss from each set of features.

${ }^{5}$ Average of four separate determinations of total heat loss by evaporation, conduction, and radiation from all five pools plus an average heat loss of $0.7 \mathrm{MW}$ from the streams draining these pools.

${ }^{6}$ From Equation 7, assuming $\mathrm{T}_{15 \mathrm{~cm}}=35^{\circ} \mathrm{C}$ over 20 percent of total area, $50^{\circ} \mathrm{C}$ over 60 percent of total area, and $80^{\circ} \mathrm{C}$ over 20 percent of total area.

${ }^{7}$ Average value of $\mathrm{H}_{\mathrm{ADV}}$ based on measurement of streamflow and temperature during late summer and fall when flow was $<10 \mathrm{~L} / \mathrm{s}$. A reference temperature of $4^{\circ} \mathrm{C}$ was assumed. 
The range of measurements of temperature and flow rate for the strongest fumarolic vents at Bumpass Hell are listed in table 3, along with similar data for three other thermal areas in LVNP with superheated vents. At Bumpass Hell, only five vents have well-defined and safely accessible vent areas suitable for flow rate measurements. MF 38 is located in the Big Boiler area, for which a vent temperature of $159^{\circ} \mathrm{C}$ was measured in 1979 (Muffler and others, 1982). Since 1987 there have been several superheated vents in this area, some near ground level adjacent to a vigorously boiling pool and some on the hillside west of the pool. The range of temperature and velocity measured in this area reflects in part the difficulty of gaining access to the same vent each visit. The maximum temperature in each vent was often particularly difficult to determine because of poor accessibility. Thus, it is difficult to evaluate whether there has been any long-term change in the degree of superheat in steam supply to this general vent area.

Calculated fumarolic heat discharges range from 0.12 to $0.27 \mathrm{MW}$ for the strongest vents at Bumpass Hell. These results, along with a few measurements in lower-velocity, lowertemperature vents, were used as references for estimating the total heat loss from approximately 30 fumaroles at Bumpass Hell. This was done by assigning values of 0.025 (low heat discharge), 0.1 (intermediate heat discharge), or $0.25 \mathrm{MW}$ (high heat discharge) to each steam vent or drowned fumarole in the upper and lower basins. Although the temperature and area of many individual vents at each thermal area varied between annual visits during this study, the total number of such vents and their general location within each thermal area did not change significantly.

Advective heat loss from the upper basin was estimated from 21 measurements of flow rate and temperature at a flume installed in 1984 in Bumpass Creek below the thermal features. Table 4 summarizes the results under low-flow conditions in late summer and fall and high-flow conditions in late spring and early summer. The average heat loss under low-flow conditions $(0.47 \mathrm{MW})$ is almost an order of magnitude lower than under high-flow conditions (3.5 MW). We expect that during high-flow periods when snowmelt increases runoff and infiltration, ground temperatures and pool temperatures are lowered and that heat is removed from shallow rocks and soils in the unsaturated zone to supply the excess advective heat loss. No measurements have been made to confirm this, however. For the purpose of estimating total heat loss, we utilized the advective heat loss results from the late summer and fall measurements. This was done for several reasons, including the greater number of measurements and the fact that timing and magnitude of peak streamflows at these thermal areas tend to vary each year as a function of the snowfall and snowmelt patterns. We assume that because streamflows at each area tend to return to the same values in late summer and fall, rates of heat loss evaluated at such times are better indications of average conditions over the year.

Most of the advective heat loss from the upper basin is derived from outflow from the five pools noted above. Within the lower basin at Bumpass Hell, hot-water inflow from several acidic springs causes a temperature increase in Bumpass Creek of about $2^{\circ} \mathrm{C}$ during low-flow conditions. This corresponds to an advective heat loss of less than $0.1 \mathrm{MW}$.

As discussed previously, measurements of sulfate outflow from steam-heated thermal areas such as Bumpass Hell provide a rough measure of the rate of steam upflow and associated heat input from the underlying vapor-dominated zone. To convert measured values of sulfate outflow to steam upflow (eq. 8), we use fumarolic gas data from Bumpass Hell (Muffler and others, 1982) to 
Table 3.--Range of measurements in superheated fumaroles at various thermal areas in Lassen Volcanic National Park over the period 1987-93

[m/s, meters per second; $\mathrm{cm}^{2}$, square centimeters; ${ }^{\circ} \mathrm{C}$, degrees Celsius; $\mathrm{kg} / \mathrm{s}$, kilograms per second; MW, megawatts]

\begin{tabular}{lcccccc}
\hline Area & ${ }^{1}$ Vent & $\begin{array}{c}{ }^{2} \mathrm{~V} \\
(\mathrm{~m} / \mathrm{s})\end{array}$ & $\begin{array}{c}{ }^{3} \mathrm{~A} \\
\left(\mathrm{~cm}^{2}\right)\end{array}$ & $\begin{array}{c}{ }^{4} \mathrm{~T} \\
\left({ }^{\circ} \mathrm{C}\right)\end{array}$ & $\begin{array}{c}{ }^{5} \mathrm{M} \\
(\mathrm{kg} / \mathrm{s})\end{array}$ & $\begin{array}{c}{ }^{6} \mathrm{H} \\
(\mathrm{MW})\end{array}$ \\
\hline \multirow{3}{*}{ Bumpass } & MF 38 & $40-100$ & $20-60$ & $110-157$ & $0.05-0.10$ & $0.12-0.27$ \\
& MF 11 & $40-83$ & $20-40$ & $93-124$ & $0.05-0.07$ & $0.13-0.18$ \\
LHSV & MF 5 & $110-130$ & $13-26$ & $138-146$ & $0.07-0.12$ & $0.19-0.33$ \\
& MF 13 & $30-70$ & $12-25$ & $93-102$ & $0.03-0.08$ & $0.07-0.21$ \\
SW & MF 95 & $87-120$ & $6-20$ & $111-116$ & $0.03-0.075$ & $0.08-0.20$ \\
& MF 99 & $22-68$ & $7-80$ & $92-105$ & $0.02-0.09$ & $0.05-0.23$ \\
DK & MF 86 & $18-54$ & 10 & $105-112$ & $0.01-0.02$ & $0.02-0.06$ \\
& MF 89 & $41-75$ & $20-60$ & $121-122$ & $0.05-0.19$ & $0.14-0.51$ \\
\hline
\end{tabular}

${ }^{1}$ MF refers to map feature numbers used on maps of Bumpass Hell and Devils Kitchen areas (Muffler and others, 1983) and on unpublished maps and air photographs of the Sulphur Works and Little Hot Springs Valley areas.

2 Velocity measurements made with pitot tube or anemometer during site visits 1987-92.

${ }^{3}$ Vent cross-sectional area estimated from visual inspections.

${ }^{4}$ Temperature of vent at land surface.

${ }^{5}$ Mass flow of steam $=\mathrm{Vx} \rho_{\mathrm{S}}$, where $\rho_{\mathrm{S}}=$ steam density at the measured vent temperature and local atmospheric pressure.

${ }^{6}$ Heat loss from vent $=M x h_{s}$, where $h_{s}=$ enthalpy of steam at the measured vent temperature and local atmospheric pressure. 
Table 4.--Average values of heat loss by advection in streams $\left(H_{A D V}\right)$ and calculated heat input to thermal area corresponding to the outflow of dissolved sulfate $\left(H_{S}\right)$, based on measurements made over the period 1984 - 93, Lassen Volcanic National Park

[nm, not measured; L/s, Liters per second; MW, megawatts]

\begin{tabular}{|c|c|c|c|c|c|c|}
\hline \multirow[b]{2}{*}{$\begin{array}{l}\text { Thermal } \\
\text { Area }\end{array}$} & \multicolumn{3}{|c|}{${ }^{1}$ Low flow conditions } & \multicolumn{3}{|c|}{${ }^{2}$ High flow conditions } \\
\hline & $\begin{array}{c}Q \\
(\mathrm{~L} / \mathrm{s})\end{array}$ & $\begin{array}{l}\mathrm{H}_{\mathrm{ADV}} \\
(\mathrm{MW})\end{array}$ & $\underset{(\mathrm{MW})}{\mathrm{H}_{\mathrm{S}}}$ & $\begin{array}{c}Q \\
(\mathrm{~L} / \mathrm{s})\end{array}$ & $\begin{array}{l}\mathrm{H}_{\mathrm{ADV}} \\
(\mathrm{MW})\end{array}$ & $\underset{(\mathrm{MW})}{\mathrm{H}_{\mathrm{S}}}$ \\
\hline $\begin{array}{l}\text { Bumpass } \\
\text { Hell }\end{array}$ & $\begin{array}{c}4.0 \pm 2.4 \\
(18)\end{array}$ & $\begin{array}{c}{ }^{3} 0.53 \pm 0.33 \\
\text { (17) }\end{array}$ & $\begin{array}{c}1.9 \pm 1.6 \\
(16)\end{array}$ & $\begin{array}{c}33 \pm 15 \\
(5)\end{array}$ & $\begin{array}{c}34.4 \pm 1.5 \\
\text { (5) }\end{array}$ & $\begin{array}{c}4.0 \pm 1.0 \\
\text { (4) }\end{array}$ \\
\hline $\begin{array}{l}\text { Sulphur } \\
\text { Works }\end{array}$ & $\begin{array}{c}75 \pm 21 \\
(13)\end{array}$ & $\begin{array}{c}{ }^{4} 2.5 \pm 1.2 \\
(13)\end{array}$ & $\begin{array}{c}7.9 \pm 2.0 \\
(13)\end{array}$ & $\begin{array}{c}685 \pm 340 \\
\text { (3) }\end{array}$ & $\begin{array}{c}{ }^{4} 11 \pm 7.4 \\
\text { (3) }\end{array}$ & $\begin{array}{c}29 \pm 4.5 \\
\text { (2) }\end{array}$ \\
\hline LHSV $^{5}$ & $\begin{array}{c}5_{52} \pm 18 \\
(7)\end{array}$ & $\begin{array}{c}66.7 \pm 2.0 \\
(7)\end{array}$ & $\begin{array}{c}2.0 \pm 0.9 \\
\text { (7) }\end{array}$ & $\begin{array}{r}{ }^{5} 224 \\
(1)\end{array}$ & $\begin{array}{r}613.9 \\
(1)\end{array}$ & $\begin{array}{l}3.8 \\
(1)\end{array}$ \\
\hline DK & $\begin{array}{c}{ }^{5} 250 \pm 70 \\
\text { (12) }\end{array}$ & $\begin{array}{c}{ }^{6} 10.4 \pm 2.7 \\
(12)\end{array}$ & $\begin{array}{l}2.0 \pm 0.45 \\
\text { (9) }\end{array}$ & $\begin{array}{c}910 \pm 200 \\
\text { (3) }\end{array}$ & $\begin{array}{c}{ }^{6} 24 \pm 4.4 \\
\text { (3) }\end{array}$ & $\mathrm{nm}$ \\
\hline
\end{tabular}

${ }^{1}$ Conditions typically encountered in late summer and fall; numbers in ( ) indicate number of measurements.

${ }^{2}$ Conditions typically encountered in spring and early summer; numbers in ( ) indicate number of measurements. Listed values for Bumpass Hell include data from measurements made in August, 1983.

${ }^{3}$ Based on measured temperatures and flows at the flume, and a reference temperature of $4^{\circ} \mathrm{C}$.

${ }^{4}$ Based on measured temperatures and flows of streams draining through East, Central, and West culverts, and a reference temperature of $4^{\circ} \mathrm{C}$.

${ }^{5}$ Average of upstream and downstream flows.

${ }^{6}$ Calculated from the difference in heat content between upstream and downstream sites. 
determine a molar ratio of steam to $\mathrm{H}_{2} \mathrm{~S}$ of approximately 1,290 to 1 . This converts to a molar ratio of steam to sulfate derived from oxidation of the $\mathrm{H}_{2} \mathrm{~S}$ of 240 to 1 . Then, for a steam enthalpy of $2,800 \mathrm{~kJ} / \mathrm{kg}$, the measured values of sulfate outflow at the flume can be converted to rates of heat input from steam upflow by multiplying by a factor of $0.67 \mathrm{MW}$ per $\mathrm{g} / \mathrm{s}$ sulfate outflow (eq. 8). The resulting values of $\mathrm{H}_{\mathrm{S}}$ in table 4 yield an average value of $1.8 \mathrm{MW}$ for 15 measurements made under low-streamflow conditions. In spite of the large variability, it is clear that $\mathrm{H}_{\mathrm{S}}$ is greater than $\mathrm{H}_{\mathrm{ADV}}$ under low-flow conditions and is comparable to $\mathrm{H}_{\mathrm{ADV}}$ during periods of high streamflow. The difference between the two quantities under low-flow conditions is to be expected because some of the steam input from the underlying vapor zone discharges from fumaroles and hot pools and does not contribute to the advective heat flow in the creek. Under high-flow conditions, $\mathrm{H}_{\mathrm{ADV}}$ increases (from capture of stored heat and increased outflow from the hot pools) more substantially than $\mathrm{H}_{\mathrm{S}}$ to bring the two quantities closer together. At such times, however, $\mathrm{H}_{\mathrm{S}}$ is significantly less than the total heat loss of $29 \mathrm{MW}$, most of which is lost by evaporation from the hot pools. Unless there is a large spring-time pulse of sulfate in the creek that we missed in our measurement set, it appears that much of the sulfur input is stored in the thermal pools and soils in the basin.

\section{Sulphur Works}

Sulphur Works (called Supan's Springs by Day and Allen, 1925) straddles the Park road $1.5 \mathrm{~km}$ north of the southern entrance to the Park at an average elevation of $2,150 \mathrm{~m}$. Its location is approximately coincident with the eroded center of Brokeoff volcano, which represents the andesite cone-building stage of the Lassen volcanic center (Clynne and Muffler, 1989). Most of the thermal area is bare ground at various stages of hydrothermal alteration. Hydrothermal manifestations include hot springs, fumaroles and drowned fumaroles, and mudpots and frying pans. There are no large hot pools at Sulphur Works, but thermal water drains into three tributaries of West Sulphur Creek (fig. 4). Thermal features such as fumaroles and frying pans occur primarily in a lower area near the Park road and boardwalk, in an upper area located approximately $0.8 \mathrm{~km}$ to the north, and along the easternmost tributary of West Sulphur Creek.

The total estimated heat loss $(10 \pm 3 \mathrm{MW})$ from the Sulphur Works area (table 5) is more evenly distributed among different types of features than at Bumpass Hell (table 2). During periods of relatively low infiltration and streamflow, the largest component ( $3 \mathrm{MW})$ is heat loss from fumarolic vents, including drowned fumaroles and frying pans. Only two areas of superheated fumarolic vents have existed at Sulphur Works since 1986; one (MF 95) occurs in the lower area adjacent to the Park road, and the other (MF 99) occurs in the upper area near several boiling mudpots. The position of the hottest vent at each area has varied over distances of about 1-2 m between visits. Calculated heat loss for the hottest vents at each area range from $0.05-0.23 \mathrm{MW}$. A value of about 0.2 is representative of the total heat loss from each of these fumarolic areas, and as such is comparable to values for MF 38 at Bumpass Hell. Values of 0.1$0.2 \mathrm{MW}$ were assigned to approximately 14 steam vents and drowned fumaroles to estimate the total $\mathrm{H}_{\mathrm{FUM}}$ for the Sulphur Works area.

Conspicuous in the lower part of the thermal area are frying pans which consist of flat areas, 2-3 m across, with gas, steam, and hot water discharging in ebullient mixtures. Heat loss from these features was estimated at twice the rate calculated for evaporation from a calm 
Table 5.--Heat loss from different types of features at the Sulphur Works thermal area, Lassen Volcanic National Park

[--, no data; $\mathrm{m}^{2}$, square meters; $\mathrm{MW}$, megawatts]

\begin{tabular}{|c|c|c|c|}
\hline $\begin{array}{l}{ }^{1} \text { Type of } \\
\text { Feature }\end{array}$ & $\begin{array}{l}\text { Number of } \\
\text { Features }\end{array}$ & $\begin{array}{l}{ }^{2} \text { Area } \\
\left(\mathrm{m}^{2}\right)\end{array}$ & $\begin{array}{c}{ }^{3} \text { Heat Loss } \\
\text { (MW) }\end{array}$ \\
\hline
\end{tabular}

Fumaroles

23

$--$

$3 \pm 1$

$1987-92$

Water surfaces

1

800

${ }^{5} 0.5 \pm 0.2$

1986

Bare ground

$\begin{array}{ll}- & 57,200\end{array}$

${ }^{6} 4 \pm 2$

1986

Streamflow

${ }^{7} 2.5 \pm 1.2$

1984-93

$\{13\}$

Totals

$\begin{array}{ll}-- & 58,000\end{array}$

$10 \pm 3$

${ }^{1}$ Fumaroles include steam vents, drowned fumaroles, and frying pans; Water Surfaces refers to the tributary of West Sulphur Creek that drains through the East Culvert; Streamflow includes the tributaries of East Sulphur Creek where they flow through the East, Central, and West culverts.

2 Total area of anomalously warm ground determined from infrared photos analyzed by Friedman and Frank (1978), topographic maps, and ground-temperature measurements.

${ }^{3}$ Calculated or estimated $1 \sigma$ uncertainties shown with \pm . Uncertainty for total heat loss calculated from the square root of the sum of squares of $\sigma$ 's for each type of feature.

${ }^{4}$ Years during which one or more visits were made; \{Number\} is the number of observations of heat loss from each set or partial set of features.

${ }^{5}$ Heat loss by evaporation, radiation, and conduction from stream draining through the East Culvert (average temperature $=20^{\circ} \mathrm{C}$ ).

${ }^{6}$ From Equation 7 , assuming $\mathrm{T}_{15 \mathrm{~cm}}=35^{\circ} \mathrm{C}$ over 80 percent of total area and $80^{\circ} \mathrm{C}$ over 20 percent of total area.

${ }^{7}$ Average value of $\mathrm{H}_{\mathrm{ADV}}$ based on measurements of the excess temperature (above $4^{\circ} \mathrm{C}$ ) in the West Sulphur Creek tributaries draining through the East, Central, and West Culverts, under low-flow conditions (combined flow $<120 \mathrm{~L} / \mathrm{s}$ ) in late summer and fall. 
surface of the same area and temperature. This estimate accounts for the enhanced evaporation rate due to ebullition, as described by Dawson (1964). For a typical frying pan at Sulphur Works, this calculation yields a heat flow of about $0.3 \mathrm{MW}$, comparable to the figure for the superheated fumaroles at Bumpass Hell. Several ebullient mudpots in the upper area discharge heat at rates estimated to be equivalent to that for the frying pans.

Heat loss from bare ground ( $4 \pm 2 \mathrm{MW}$ ) was calculated for heat flows of $300 \mathrm{~W} / \mathrm{m}^{2}$ over 20 percent of the area of heated ground and $10 \mathrm{~W} / \mathrm{m}^{2}$ over the remaining 80 percent, based on equation 7 and average ground temperatures of $35^{\circ} \mathrm{C}$ and $80^{\circ} \mathrm{C}$, respectively. The total area of heated ground $\left(58,000 \mathrm{~m}^{2}\right)$ was determined from air photos, topographic maps, and groundtemperature measurements. It is considerably less than the total area of altered ground $(\sim 0.5 \mathrm{~km})$ drained by the three tributaries of West Sulphur Creek.

Advective heat losses from the Sulphur Works area were determined for the three tributaries noted above where they flow through culverts near the park road, referred to here as the East, Central, and West culvert stations. Most of this heat is carried in the East culvert drainage, along which the most active vents are located. Measurements of streamflow, temperature, and $\mathrm{SO}_{4}$ concentration have been made on these streams on 16 occasions since 1984 at sections immediately upstream from the culverts. Values of total advective heat loss for the three streams, calculated for an assumed reference temperature of $4^{\circ} \mathrm{C}$ (as at Bumpass Hell) averaged $2.5 \mathrm{MW}$ for the low-flow periods and $8.4 \mathrm{MW}$ for high-flow periods (table 4). Rates of advective heat loss during high-flow periods are comparable to the total heat loss from this area under low-flow conditions. This same aspect is observed at all the other major thermal areas at Lassen, except at Bumpass Hell and Boiling Springs Lake where the total heat loss is dominated by evaporation from large hot pools. Given the areas of heated soils at Sulphur Works, Little Hot Springs Valley, and Devils Kitchen, sufficient heat could be removed from the upper few meters of soil and rock by infiltrating water to provide the excess advective heat, given only a few degrees of cooling. It is also possible that seasonal changes in the depth to the water table over these thermal areas result in changes in the rate of input of heated ground water to each drainage system.

Values of $\mathrm{H}_{\mathrm{S}}$ for the east and central culvert streams calculated from equation 8 yielded average values of $7.9 \mathrm{MW}$ during low-flow periods and $29 \mathrm{MW}$ during high-flow periods. Both quantities are significantly higher than the corresponding values of $\mathrm{H}_{\mathrm{ADV}}$, most probably reflecting the influence of dissolved sulfate contributed to the drainages at Sulphur Works from non-active sources, for example, hydrothermally altered soil. This effect is also indicated by the fact that values of $\mathrm{H}_{\mathrm{S}}$ under high-flow conditions are approximately twice as large as the total heat loss under low-flow conditions.

\section{Little Hot Springs Valley}

The Little Hot Springs Valley thermal area is situated in a steep, narrow valley between Bumpass Hell and Sulphur Works (fig. 4). The average elevation of the most active part of this area is $2,130 \mathrm{~m}$. Prominent thermal features include fumaroles and related features (drowned fumaroles and frying pans), hot springs, and East Sulphur Creek, which is warmed to temperatures above $30^{\circ} \mathrm{C}$ by hot-water inflow and steam condensation as it drains through the valley. Several areas of superheated fumaroles occur near the banks of the creek, with measured 
temperatures as high as $143^{\circ} \mathrm{C}$ in one area. Although there are no published maps of locations of thermal features in this area, an unpublished inventory with locations referenced to air photographs was prepared by L.J.P. Muffler in 1982.

Heat loss from this area $(15 \pm 3 \mathrm{MW})$ is nearly equally distributed between advection in East Sulphur Creek, discharge from fumaroles and related features, and heat loss from bare ground (table 6). Heat loss from bare ground $(4 \pm 2 \mathrm{MW})$ was calculated from assumed heat flows of 10,40 , and $300 \mathrm{~W} / \mathrm{m}^{2}$ assigned to subareas of the total area of bare heated ground $\left(78,000 \mathrm{~m}^{2}\right)$. Thermal features are located primarily in or near East Sulphur Creek and its tributaries (fig. 4).

Heat discharge from approximately 40 fumarolic features is estimated at $4 \pm 2 \mathrm{MW}$. The range of measured values for two of the largest fumaroles located adjacent to the creek (table 3) show that temperature and velocity in vent MF 5 have consistently been higher than at any other vent in the Park, yielding a maximum heat output in October 1992 of 0.41 MW. Velocities and heat outputs in vent MF 13 are considerably lower ( $50 \mathrm{~m} / \mathrm{s}$ and $0.07 \mathrm{MW}$, respectively), but more representative of most of the fumaroles in Little Hot Springs Valley. Average heat outputs determined for these two vents were used as references for estimating the total heat discharge in fumarolic features in LHSV.

Advective heat loss represents the largest component $(6.7 \pm 2.0 \mathrm{MW})$ of the total heat loss for this area. Values of $\mathrm{H}_{\mathrm{ADV}}$ were calculated from 7 measurements of the difference between the heat content of East Sulphur Creek at sites above and below the thermal features that drain into the creek. Streamflows at the downstream site were between $28 \mathrm{~L} / \mathrm{s}$ and $82 \mathrm{~L} / \mathrm{s}$ for this data set (table 4). Only one measurement of advective heat loss at a higher flow rate (about $220 \mathrm{~L} / \mathrm{s}$ ) was made; the corresponding value of $\mathrm{H}_{\mathrm{ADV}}$ for this August 1983 measurement was $13.9 \mathrm{MW}$. Unfortunately, access to the gaging sites during the spring and early summer period is hazardous.

Unlike results for Bumpass Hell and Sulphur Works, values of $\mathrm{H}_{\mathrm{S}}$ associated with the measured increase in sulfate outflow between the measuring sections in East Sulphur Creek are consistently lower than corresponding values of $\mathrm{H}_{\mathrm{ADV}}$. This suggests that much of the sulfur input accompanying steam and gas upflow ends up as deposits in the shallow soils adjacent to the creek rather than being fully oxidized and dissolved in the creek water. Values of sulfate outflow at the upstream measuring site are relatively large and may signify some inputs of steam and gas from thermal features above this site and/or inputs of sulfate from erosion of bank sediments. Creek temperatures at this site were typically close to the air temperature.

\section{Devils Kitchen}

The Devils Kitchen thermal area consists of a deep narrow valley drained by Hot Springs Creek. The average elevation of the thermal area is $1,750 \mathrm{~m}$; it contains many boiling springs near stream level and numerous weak, or low-velocity fumaroles at higher elevations. Advection in Hot Springs Creek is the dominant mode of heat loss (table 7). Temperatures in the creek increase by about $10^{\circ} \mathrm{C}$ as it flows through the thermal area. The hot springs are derived from steam-heated ground water; their combined flow is close to $25 \mathrm{~L} / \mathrm{s}$. Measured temperatures of fumarolic vents ranged from $93-112^{\circ} \mathrm{C}$ over the $1988-1990$ period. During a visit in August 
Table 6.--Heat loss from different types of features at the Little Hot Springs Valley thermal area, Lassen Volcanic National Park

[--, no data; , approximately equal to; $\mathrm{m}^{2}$, square meters; MW, megawatts]

\begin{tabular}{|c|c|c|c|}
\hline $\begin{array}{l}{ }^{1} \text { Type of } \\
\text { Feature }\end{array}$ & $\begin{array}{l}\text { Number of } \\
\text { Features }\end{array}$ & $\begin{array}{l}{ }^{2} \text { Area } \\
\left(\mathrm{m}^{2}\right)\end{array}$ & $\begin{array}{c}{ }^{3} \text { Heat Loss } \\
\text { (MW) }\end{array}$ \\
\hline
\end{tabular}

Fumaroles

$-$

$4 \pm 2$

$1987-92$

Water surfaces

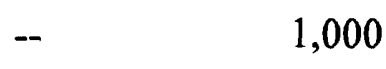

${ }^{5} 0.5 \pm 0.2$

1987

Bare ground

$--\quad 78,000$

${ }^{6} 4 \pm 2$

1987

Streamflow

$--$

${ }^{7} 6.7 \pm 2.0$

$1987-92$

Totals

$-79,000 \quad 15 \pm 3$

${ }^{1}$ Fumaroles includes steam vents and drowned fumaroles; Water Surfaces includes springs, pools, mud pots, and East Sulphur Creek; Streamflow refers to East Sulphur Creek where it discharges from the thermal area.

${ }^{2}$ Total area of anomalously warm ground determined from topographic maps and groundtemperature measurements.

${ }^{3}$ Calculated or estimated $1 \sigma$ uncertainties shown with \pm . Uncertainty in total head loss calculated from the square root of the sum of squares of $\sigma$ 's for each type of feature.

${ }^{4}$ Years during which one or more visits were made; \{Number $\}$ is the number of observations of heat loss from each set of features.

${ }^{5}$ Heat loss by evaporation, radiation, and conduction from water surfaces.

${ }^{6}$ From Equation 7 , assuming $\mathrm{T}_{15 \mathrm{~cm}}=80^{\circ} \mathrm{C}$ over 10 percent of total area, $50^{\circ} \mathrm{C}$ over 30 percent, and $35^{\circ} \mathrm{C}$ over 60 percent.

${ }^{7}$ Average value of $\mathrm{H}_{\mathrm{ADV}}$, based on increase in temperature of East Sulphur Creek between upper and lower gaging sites, measured under low-flow conditions $(\leq 75 \mathrm{~L} / \mathrm{s})$ in late summer and fall. 
Table 7.--Heat loss from different types of features at the Devils Kitchen thermal area, Lassen Volcanic National Park

[--, no data; $\mathrm{m}^{2}$, square meters; $\mathrm{MW}$, megawatts $]$

$\begin{array}{cccc}{ }^{1} \text { Type of } & \text { Number of } & & \\ \text { Feature } & \text { Features } & { }^{2} \text { Area } & { }^{3} \text { Period of } \\ \left(\mathrm{m}^{2}\right) & \text { (MW) } & \begin{array}{c}\text { Observation } \\ \text { \{Number }\end{array}\end{array}$

Fumaroles

48

$--\quad 2 \pm 1$

1988-93

$\{4\}$

Water surfaces

45

1,900

$5_{3} \pm 1$

1986

Bare ground

$-\quad 39,000$

${ }^{6} 6 \pm 3$

1986

Streamflow

$\begin{array}{lll}- & - & \end{array}$

1986-93

$\{12\}$

Totals

$-\quad 40,900 \quad 21 \pm 4$

${ }^{1}$ Fumaroles includes steam vents and drowned fumaroles; Water Surfaces includes springs, pools, mud pots, and Hot Springs Creek; Streamflow refers to Hot Springs Creek where it discharges from the thermal area.

2 Total area of anomalously warm ground determined from infrared photos analyzed by Friedman and Frank (1978).

${ }^{3}$ Calculated or estimated $1 \sigma$ uncertainties shown with \pm . Uncertainty for total heat loss calculated from the square root of the sum of squares of $\sigma$ 's for each type of feature.

${ }^{4}$ Years during which one or more visits were made; $\{$ Number $\}$ is the number of observations of heat loss from each set or partial set of features.

${ }^{5}$ Heat loss by evaporation or partial radiation, and conduction from water surfaces.

${ }^{6}$ From Equation 7, assuming $\mathrm{T}_{15 \mathrm{~cm}}=50^{\circ} \mathrm{C}$ over 50 percent of total area, $80^{\circ} \mathrm{C}$ over 40 percent, and $35^{\circ} \mathrm{C}$ over the remaining 10 percent.

${ }^{7}$ Average value of $\mathrm{H}_{\mathrm{ADV}}$, based on measurements of increase in temperature in Hot Springs Creek between an upper gaging site (just below the falls) and a lower gaging site just below the site of the former lower bridge, for average flows $\leq 430 \mathrm{~L} / \mathrm{s}$. 
1992 , however, several high-velocity vents were measured at temperatures close to $122^{\circ} \mathrm{C}$. The total heat loss for this area is estimated to be approximately $21 \pm 4 \mathrm{MW}$.

Fumaroles issue from a steep, bouldery hillslope on the south side of the creek. The vents sampled during the course of this study are situated near the eastern, or downstream end of the thermal area and approximately $20 \mathrm{~m}$ above the level of the creek. Vent designations referred to in this section are those used by Muffler and others (1983) on a published map of the Devils Kitchen area. Prior to the visit in August 1992, only vent MF 86 was suitable for velocity measurements and gas sampling; the calculated heat flows from this vent were 0.021 and 0.062 MW in 1988 and 1989, respectively (table 3). In 1990, this vent was too weak to get a reliable velocity measurement and temperatures were near $93^{\circ} \mathrm{C}$ throughout the fumarolic area. In August 1992 , however, the output of three closely spaced vents in the vicinity of feature MF 89 , located approximately $5 \mathrm{~m}$ higher upslope from MF 86 totaled $0.92 \mathrm{MW}$. Steam discharge from other vents areas at Devils Kitchen did not appear from visual inspection to have been significantly greater than during previous visits. The increased steam discharge at the MF 89 vent area increased the estimated heat loss from fumaroles from $1 \mathrm{MW}$ to $2 \mathrm{MW}$.

The total area of altered ground at Devils Kitchen was mapped by Muffler and others (1983) as approximately $61,000 \mathrm{~m}^{2}$. Interpretations of infrared imagery from satellite photos suggests an area of heated ground of $40,900 \mathrm{~m}^{2}$ (Friedman and Frank, 1978). Using the latter estimate, and assuming heat flows of 300,40 , and $10 \mathrm{~W} / \mathrm{m}^{2}$ over 40,50 , and 10 percent of the total area, respectively, we estimate the heat loss from bare ground as $6 \pm 3 \mathrm{MW}$. An estimated $3 \mathrm{MW}$ is also lost by various modes from the surfaces of spring pools, their drainage channels, and Hot Springs Creek.

Advective heat flow in Hot Springs Creek is the dominant mode of heat loss from the Devils Kitchen area. Estimates of heat added to the creek as it drains through the thermal area have been made on 12 occasions since 1986, based on measurements of streamflow and temperatures at sites above (just below the falls) and below (just below the lower bridge site) the thermal features. The average values of streamflow and $\mathrm{H}_{\mathrm{ADV}}$ are $250 \mathrm{~L} / \mathrm{s}$ and $10.4 \mathrm{MW}$, respectively (table 4). Although these measurements were made under conditions of relatively low streamflow, there is a general correlation between streamflow and heat discharge, indicating that advective heat loss increases with increasing runoff. On a few occasions streamflow and/or temperature were measured at a third site located $75 \mathrm{~m}$ farther downstream from the lower bridge site. Calculated heat contents at this third site were approximately 10-20 percent higher than at the lower bridge site, as a result of seepage of heated ground water into the stream between these two downstream sites.

Several measurements of $\mathrm{H}_{\mathrm{ADV}}$ were made prior to 1986 under conditions of higher streamflow, as reported by Friedman and Frank (1978) and by Day and Allen (1925). A similar method was used on these occasions, although the actual locations of gaging sites are were not reported (except that Friedman and Frank specify that the upstream site they gaged was $100 \mathrm{~m}$ above the falls). The average values of streamflow and $\mathrm{H}_{\mathrm{ADV}}$ for this set of three measurements are and $900 \mathrm{~L} / \mathrm{s}$ and $24 \mathrm{MW}$, respectively. The individual values of advective heat loss are 29 MW (July 1922), 21 MW (August 1923), and 22 MW (July 1974). Comparison with our 19861993 data suggests that the higher values of advective heat loss measured by previous investigators resulted primarily from the transient heat mining effect noted for other thermal areas at Lassen. 
The average value of heat loss indicated by the sulfate outflow in Hot Springs Creek (2.0 MW) is about $1 / 5$ of the corresponding value of $\mathrm{H}_{\mathrm{ADV}}$ under low-flow conditions, as was the case for the Little Hot Springs thermal area. No estimates of sulfate outflow are available for periods of relatively high streamflow.

\section{Boiling Springs Lake}

Boiling Springs Lake thermal area is an oval basin of hydrothermally altered ground containing a large lake of warm, low $\mathrm{pH}$ water. Lake elevation is $1,800 \mathrm{~m}$. Hot springs and weakly pressurized fumaroles surround portions of the lake. The dominant mode of heat loss from the area is evaporation from the lake surface. We estimate a total heat loss from this area of 37 $\pm 4 \mathrm{MW}$ (table 8), based on data collected during visits on October 1986 and August 1988 and comparisons with an estimate obtained by Friedman and Frank (1978) for October 1972. Both the total heat loss and the average heat flow $\left(2,600 \mathrm{~W} / \mathrm{m}^{2}\right)$ are larger than corresponding values for any other thermal area in the Park.

In October 1986, an average lake-surface temperature of $48^{\circ} \mathrm{C}$ and an air temperature of $10^{\circ} \mathrm{C}$ were recorded, but no actual measurements of lake area were made. In August 1988, we measured an average lake-surface temperature of $52^{\circ} \mathrm{C}$ (air temperature $32^{\circ} \mathrm{C}$ ) and a lake area of $12,000 \mathrm{~m}^{2}$. During the latter visit, a lake area of $12,000 \mathrm{~m}^{2}$ was measured with surveying equipment and high-water marks were used to measure a maximum lake area of $13,000 \mathrm{~m}^{2}$. The area of warm ground surrounding the lake was estimated to be $2,300 \mathrm{~m}^{2}$ during the 1988 visit. No surface outflow from the lake existed at the time of the 1988 visit, whereas a small $(0.5 \mathrm{~L} / \mathrm{s})$ outflow from the northeastern edge of the lake was observed in October 1986. Surface outflow and a cooler lake temperature indicate that the lake surface area was greater in October 1986 than in August 1988.

Values of heat loss by different modes were calculated for conditions existing at the time of each visit. For the October 1986 visit, a lake area of $13,000 \mathrm{~m}^{2}$ and an area of warm ground of $1,300 \mathrm{~m}^{2}$ were assumed. For each visit a heat flow from warm ground of $40 \mathrm{~W} / \mathrm{m}^{2}$ was estimated from limited ground-temperature measurements. Results listed below for each visit are in reasonable agreement, so that the average value of total heat loss $(37 \mathrm{MW})$ is used in table 8 .

$\begin{array}{lcc}\text { Date: } & \text { October } 23,1986 & \text { August } 19,1988 \\ \mathrm{~T}_{\text {water }} & 48^{\circ} \mathrm{C} & 52^{\circ} \mathrm{C} \\ \mathrm{H}_{\text {EVAP }} & 25.8 \mathrm{MW} & 29.9 \mathrm{MW} \\ \mathrm{H}_{\text {COND }} & 4.9 \mathrm{MW} & 5.7 \mathrm{MW} \\ \mathrm{H}_{\text {RAD }} & 3.6 \mathrm{MW} & 3.7 \mathrm{MW} \\ \mathrm{H}_{\mathrm{GR}} & 0.1 \mathrm{MW} & 0.1 \mathrm{MW} \\ \mathrm{H}_{\text {ADV }} & 0.1 \mathrm{MW} & 0 \mathrm{MW} \\ \mathrm{H}_{\text {TOTAL }} & 34.4 \mathrm{MW} & 39.4 \mathrm{MW}\end{array}$

Friedman and Frank (1978) obtained a value of $31 \mathrm{MW}$ for total heat loss from the lake, based on a similar mathematical formulation, but using values for lake area and temperature of $15,700 \mathrm{~m}^{2}$ and $43^{\circ} \mathrm{C}$, respectively. The lake area used by Friedman and Frank was obtained from infrared imagery, and may in fact include areas of warm ground surrounding the lake. They estimated the 
Table 8.--Summary of total heat loss, heat flow, and inferred rate of steam upflow at thermal areas in Lassen Volcanic National Park, listed in order of decreasing heat loss and steam upflow

[nm, not measured; $\mathrm{m}^{2}$, square meters; $\mathrm{MW}$, megawatts; $\mathrm{W} / \mathrm{m}^{2}$, watts per square meter; $\mathrm{kg} / \mathrm{s}$, kilograms per second]

\begin{tabular}{lcccc}
\hline Thermal Area & $\begin{array}{c}{ }^{1} \text { Size } \\
\left(\mathrm{m}^{2}\right)\end{array}$ & $\begin{array}{c}{ }^{2} \text { Heat Loss } \\
(\mathrm{MW})\end{array}$ & $\begin{array}{c}{ }^{3} \text { Heat Flow } \\
\left(\mathrm{W} / \mathrm{m}^{2}\right)\end{array}$ & $\begin{array}{c}{ }^{4} \text { Steam Upflow } \\
(\mathrm{kg} / \mathrm{s})\end{array}$ \\
\hline Boiling Springs Lake & 14,300 & $37 \pm 5$ & 2,600 & 13 \\
Bumpass Hell & 46,000 & $29 \pm 4$ & 630 & 10 \\
Devils Kitchen & 40,900 & $21 \pm 4$ & 510 & 8 \\
Little H.S. Valley & 79,000 & $15 \pm 3$ & 190 & 5 \\
Sulphur works & 58,000 & $10 \pm 3$ & 120 & 4 \\
Pilot Pinnacle & 7,500 & $2 \pm 1$ & 300 & 0.7 \\
Terminal Geyser & 900 & $1 \pm 0.5$ & 1,000 & 0.4 \\
Lassen Peak & 3,500 & $0.3 \pm 0.2$ & 90 & 0.1 \\
Drakesbad & 10,000 & $0.1 \pm 0.05$ & 10 & 0 \\
\cline { 2 - 5 } & -- & $115 \pm 9$ & -- & 41 \\
Totals & & & & \\
\hline
\end{tabular}

${ }^{1}$ Area of heated ground.

${ }^{2} 1 \sigma$ uncertainties shown with \pm . Uncertainty in total heat loss calculated from the square root of the sum of squares of $\sigma$ 's for heat loss from each area.

3 Average heat loss divided by the area of heated ground.

${ }^{4}$ Average heat loss divided by $2800 \mathrm{~kJ} / \mathrm{kg}$. 
outflow from the lake at $0.5 \mathrm{~L} / \mathrm{s}$. They also reported that temperature measurements at various depths in the lake were made continuously from October 1972 through January 1973 and that periodic water-surface temperature measurements were extended into 1974. Their data show a range in lake-surface temperature of $39.8-44.4^{\circ} \mathrm{C}$, and increases in water temperature with depth in the lake. Their measuring sites were located near the northeastern edge of the lake.

The lake area and temperature probably vary seasonally, with higher lake levels and surface areas being accompanied by lower water temperatures, and at times by advective heat discharge from the northern end of the lake. The estimate of total heat flow by Friedman and Frank is lower than our measured values primarily because of the lower lake temperatures at the time of their measurements. Although the rate of surface outflow from the lake was apparently no larger than that found in October 1986, there may be some subsurface ground-water discharge that accounts for the apparently lower heat loss in October 1972. In any event, we have increased the estimated uncertainty on our heat-loss value for Boiling Springs Lake (table 8) to take into account this lower value.

\section{Other Areas}

Four other areas with hydrothermal features occur within Lassen Volcanic National Park. Their combined heat loss amounts to about $3 \mathrm{MW}$ (table 8). Two of these areas occur on the flanks of Lassen Peak (fig. 4), one on the northern side of the peak (referred to here as the Lassen Peak thermal area) and one on the southwestern flank (Pilot Pinnacle thermal area). Steam discharge on the north side of Lassen Peak occurs as diffuse seepage on the summit and at two areas of altered ground at elevations of 2,400-2,800 m on the northwest flank (David Frank, U.S. Environmental Protection Agency, oral commun., 1992). Although temperatures of about $90^{\circ} \mathrm{C}$ have been measured at shallow depths in one of these areas, there are no well-defined vents from which velocity measurements or gas samples could be obtained. The total heat loss from these areas is estimated at $0.3 \pm 0.1 \mathrm{MW}$. Steam vents, drowned fumaroles, and small warm pools occur at the Pilot Pinnacle area. Temperature measurements of various features in August 1990 were all below $91^{\circ} \mathrm{C}$. A small stream draining the thermal area had a temperature of $30^{\circ} \mathrm{C}$ and a pH of 3. Total heat loss from the Pilot Pinnacle area is estimated to be $2 \pm 1 \mathrm{MW}$.

Included in the set of thermal areas located to the southeast of the Lassen Peak area are Terminal Geyser and Drakesbad. The former consists of a few vigorously jetting drowned fumaroles and adjacent areas of warm ground and weakly pressurized steam vents. We measured a vent temperature for the main feature of $106^{\circ} \mathrm{C}$ in September 1987 ; previously reported temperatures are as high as $116^{\circ} \mathrm{C}$ (Muffler and others, 1982). Total heat flow from the fumarolic features is estimated to be $1 \pm 0.5 \mathrm{MW}$; heat discharge by other modes amounts to less than 0.1 MW. Temperature profiles and hot water produced from the Walker "O" No. 1 well, located within this thermal area, indicate that the area is underlain by a permeable zone containing thermal water whose chemical content is remarkably similar to that of the hot springs located along Mill Creek south of the Park (table 1 and fig. 2). The surficial steam-heated features at Terminal Geyser could be fed by steam which boils off a localized upflow of hot water from this permeable zone or from a vapor-dominated zone that extends from this area back to the west.

The Drakesbad thermal area consists of one active spring discharging near-neutral-pH lowchloride water at a temperature of $66^{\circ} \mathrm{C}$ (table 1), and several areas of fossil sinter deposits. 
Thompson (1985) reports calculated geothermometer temperatures close to the measured spring temperature for this feature. This characteristic and the absence of steam and low-pH water discharge indicate that this area is conductively heated from an underlying hot-water aquifer, rather than being steam-heated. Our estimate of total heat flow from this area $(0.1 \mathrm{MW})$ consists of an advective heat loss in the spring flow (estimated as $0.3 \mathrm{~L} / \mathrm{s}$ ) and heat loss from bare ground, assuming a heat flow of $1.5 \mathrm{~W} / \mathrm{m}^{2}$.

\section{Uncertainty and Variability in Heat-Loss Estimates}

Our calculated total heat loss from all nine thermal areas in LVNP is $115 \pm 9 \mathrm{MW}$ (table 8), and is evenly distributed between the five thermal areas around the flanks of Lassen Peak (Bumpass Hell, Little Hot Springs Valley, Sulphur Works, Pilot Pinnacle, and Lassen Peak) and the four areas to the southeast along or near Hot Springs Creek (Devils Kitchen, Boiling Springs Lake, and Terminal Geyser). The uncertainties listed for the larger thermal areas, where direct measurements were made, range from $\pm 11-30$ percent of the total heat loss. As noted previously, these results are representative of hydrologic conditions encountered during late summer and fall when streamflows have declined to relatively low levels following the period of snowmelt and high streamflow in spring and early summer. Limited measurements made during this latter period indicate that significantly higher advective heat loss in streams occurs at several areas as heat is transferred from warm rock to infiltrating cold water and thus effectively mined from the shallow soils. This period should be followed by a period when heat is put back into storage through a combination of steam condensation and conductive heat flow. Assuming that the latter process has been accomplished before the time of our late summer-fall measurements, we could consider the heat-loss values in table 8 as representative of average conditions through the year. Although we cannot prove that this is the case, it is suggested by the consistency of our low-flow heat-loss measurements at the major thermal areas from one year to the next over the 1984-93 period. Nevertheless, it seems appropriate to consider that some additional uncertainty is introduced by seasonal variations in heat loss at each area, as well as by undetected subsurface outflow of heated ground water. Consequently, the uncertainty in our estimate of the average heat loss from all areas in the Park may be closer to \pm 20 percent of the total of $115 \mathrm{MW}$. Furthermore, from repeat measurements of advective heat loss in streams and heat loss from water surfaces, which are commonly the dominant forms of heat loss, there does not appear to have been any changes in total heat loss at each thermal area from one year to the next during our study period that would be outside of the maximum \pm 30 percent level of variability estimated for the individual areas.

\section{Calculated Heat Flows and Steam-Upflow Rates}

Values of average heat flow at the steam-heated thermal areas, calculated from the total heat loss divided by the surface area, range from $90-2,600 \mathrm{~W} / \mathrm{m}^{2}$ (table 8 ). These rates far exceed the regional conductive heat flow of about $0.08 \mathrm{~W} / \mathrm{m}^{2}$ for the Lassen region and heat flows up to 0.25 $\mathrm{W} / \mathrm{m}^{2}$ observed in shallow wells drilled south of the Park (Sorey and Ingebritsen, 1984). At Bumpass Hell, which we envision as underlain by a vapor-dominated zone at $240^{\circ} \mathrm{C}$ whose top is at a depth of about $300 \mathrm{~m}$ (Ingebritsen and Sorey, 1985), the conductive heat flow through parts of the condensate zone without steam upflow could be as high as $1.5 \mathrm{~W} / \mathrm{m}^{2}$. However, even this quantity is small compared with the measured heat flows at each area. These observations, along with the characteristics of the surficial thermal features, require that steam upflow be the primary mechanism for heat transfer into these thermal areas. 
The rate of steam upflow at each thermal area can be estimated by dividing the total heat flow by the enthalpy of upflowing steam. Steam enthalpy varies little over temperature conditions anticipated for vapor-dominated zones beneath the different thermal areas; a value of $2,800 \mathrm{~kJ} / \mathrm{kg}$ is used for each area. Calculated steam upflow rates range from $13 \mathrm{~kg} / \mathrm{s}$ at Boiling Springs Lake to $0.1 \mathrm{~kg} / \mathrm{s}$ at Lassen Peak (table 8). The estimated total steam upflow for all areas studied is 41 $\mathrm{kg} / \mathrm{s}$, which in turn produces a total heat discharge of $115 \mathrm{MW}$. As with heat loss, steam upflow is nearly evenly distributed between the thermal areas around Lassen Peak and the areas to the southeast. 


\section{COMPARISONS WITH OTHER RESULTS}

Our results can be compared with estimates made for a few of the Lassen thermal areas by Friedman and Frank (1978), using infrared imagery obtained in 1972 and limited direct measurements of streamflow and water and ground temperatures. The published values of heat loss from Bumpass Hell and Devils Kitchen from these authors are comparable but somewhat greater than our estimates for these areas. Their estimate for Bumpass Hell (37-63 MW) includes $25 \mathrm{MW}$ for "the heat advected via effluent drainage." However, this rate was not measured but instead was inferred from their measurement of advected heat at Devils Kitchen. Our data for direct measurements of $\mathrm{H}_{\mathrm{ADV}}$ at Bumpass Hell show that this quantity is less than $5 \mathrm{MW}$ even under conditions of relatively high streamflow. Subtracting $20 \mathrm{MW}$ from the total heat loss estimate of Friedman and Frank (1978) yields the range of 17-53 listed in table 9, which brackets our estimate of $29 \mathrm{MW}$. Similarly, we have reduced their published value of advective heat loss for Devils Kitchen (25 MW), which was measured under high-streamflow conditions, to match our average value for low-flow conditions (11 MW). This yields a range of 16-50 MW for total heat loss (table 9) that brackets our estimate of 22.

Heat-loss estimates made for other steam-heated thermal areas in the Cascade Range and in New Zealand are also listed in table 9. Values for the summit regions of other volcanoes in the Cascade Range have been obtained using a variety of techniques, including thermal infrared surveys, air photographs, snow calorimetry, and limited measurements of fumarolic discharge. The data for Mt. Rainier, Mt. Baker, and Mt. Hood show a consistent level of heat loss from the summit regions of about $10 \mathrm{MW}$ under quiescent conditions, apparently reflecting the fact that these are all dominantly andesitic stratocones fed by a single magmatic conduit around which steam-heated thermal features develop on the summit. Lower heat loss from these areas compared with many of the Lassen thermal areas is consistent with more vigorous surficial features at Lassen. However, significant increases in heat flux at Mt. Baker (1975) and Mt. St. Helens (1980) have been documented during periods of unrest associated with shallow intrusive activity.

Ketetahi Hot Springs is situated on the slopes of New Zealand's Mt. Tongariro, a complex andesite volcano of Quaternary age near the southern end of the Taupo volcanic zone. Ketetahi is similar in several respects to the thermal areas south of Lassen Peak, including fumarolic temperatures $\left(100-138^{\circ} \mathrm{C}\right)$, temperatures estimated for the underlying steam reservoir $(200$ $250^{\circ} \mathrm{C}$ ), and an estimated heat loss of $36 \mathrm{MW}$. Techniques similar to those used in this study have been used at Ketetahi Hot Springs to estimate heat loss from fumaroles and steam-heated ground (Hochstein and Bromley, 1979; Hochstein, 1985). Velocity measurements reported on the largest fumaroles exceed $90 \mathrm{~m} / \mathrm{s}$. During a visit to this area in November 1993 by M.L. Sorey, however, maximum fumarolic temperatures and velocities were only about $104^{\circ} \mathrm{C}$ and $60 \mathrm{~m} / \mathrm{s}$, respectively. Two smaller areas of steam discharge also occur on Mt. Tongariro; their combined heat loss is estimated at $25 \mathrm{MW}$ (Hochstein, 1985). 
Table 9.--Total heat loss and heat flow for steam-heated thermal areas at Lassen Volcanic National Park, other Cascade volcanoes, and Ketetahi Hot Springs in New Zealand

\begin{tabular}{lcccc}
\hline Location & $\begin{array}{c}\text { Total Heat Loss } \\
\text { (megawatts) }\end{array}$ & $\begin{array}{c}\text { Surface Area } \\
\text { (square meters) }\end{array}$ & $\begin{array}{l}\text { Heat Flow } \\
\text { (Watts per } \\
\text { square meter) }\end{array}$ & ${ }^{1}$ Reference \\
\end{tabular}

Lassen Park:

Bumpass Hell

1984-93

$1972-74$

$29 \pm 4 \quad 46,000$

${ }^{2} 17-53$

46,000

630

$380-1180$

This study

1

Boiling Springs Lake

1986-1988

1972-74

$37 \pm 5$

14,300

2,600

15,700

2,000

This study

31

$21 \pm 4$

40,900

540

41,000

$390-1220$

This study

1972-74

${ }^{2} 16-50$

8.6

${ }^{3} 16,000$

700

2

Upper flank fumaroles

1.0

3,000

300

2

Mt. Baker (Sherman Crater):

1972

1975

Mt. Hood:

Crater Rock/Steel Cliff

Mt. St. Helens:

Old dome, 1972

New Crater, May 1980

New Crater, August 1980

11

8,800

1,300

2,300

3

81

35,200

9.8

9,700

1,000

4

Ketetahi Hot Springs:

1976

36
0.2

30-75

$4,000-10,000$
1,000

30,000

800,000
200

1,770

8,750
4

2,6

2,7

2

${ }^{1}$ 1-Friedman and Frank (1978); 2-Frank (1985); 3-Friedman and Frank (1980); 4-Friedman et al. (1982); 5-Friedman and Frank (1977); 6-Kieffer et al (1981); 7-Friedman et al. (1981); 8Hochstein (1985); 9-Hochstein and Bromley (1979).

2 Published values for Bumpass Hell reduced by $20 \mathrm{MW}$ to correct for actual measurements of $\mathrm{H}_{\mathrm{ADV}}$; published values for Devils Kitchen reduced by $14 \mathrm{MW}$ to account for lower advective heat loss under low-streamflow conditions.

${ }^{3}$ Not counting areas of subglacial activity. 


\section{SUMMARY AND CONCLUSIONS}

Estimates of total heat loss at thermal areas in Lassen Volcanic National Park were made from direct and indirect measurements of heat loss from bare ground, fumaroles, water surfaces, and streams. The heat loss at eight steam-heated thermal areas in Lassen Volcanic National Park totals $115 \mathrm{MW}$, with an uncertainty of \pm 20 percent. Total heat loss at individual thermal areas ranges from about $30 \mathrm{MW}$ at Bumpass Hell and Boiling Springs Lake to $2 \mathrm{MW}$ or less at Terminal Geyser, Pilot Pinnacle, and Lassen Peak. The dominant mode of heat loss is evaporation from water surfaces at some thermal areas and advection in streams at other areas. The rate of advective heat loss at each area is highest during periods of high streamflow in the spring and early summer, when heat is transferred from shallow warm soils to infiltrating snow melt and surface runoff. The set of heat-loss measurements for the period 1984-93 indicates that there have been no changes in total heat loss at each thermal area larger than about \pm 30 percent of the average values determined.

Values of average heat flow at these thermal areas are anomalously high compared with probable conductive heat flow rates for this region. The anomalous heat flow must be supplied by steam upflow from underlying vapor-dominated zone(s). Calculated rates of steam upflow at individual thermal areas range from 0.1 to $13 \mathrm{~kg} / \mathrm{s}$ and total about $40 \mathrm{~kg} / \mathrm{s}$ for all eight areas in the Park. Rates of steam upflow are evenly distributed between the five thermal areas situated on the south flanks of Lassen Peak and the three areas situated to the southeast of Lassen Peak along or near Hot Springs Creek. A portion of the steam upflow at each area discharges directly at the land surface in fumaroles. Measured fumarolic temperatures range from $93-157^{\circ} \mathrm{C}$. Steam velocities measured with a pitot tube in superheated fumaroles at several thermal areas range from 18 to 130 $\mathrm{m} / \mathrm{s}$.

Heat-loss values obtained in this study by direct measurement techniques are in reasonable agreement with the range of values obtained in previous investigations utilizing a combination of infrared imagery and on-the-ground measurements. Rates of heat loss from the larger thermal areas at Lassen (10-37 MW) are also comparable to values estimated for the summit regions of other Cascade volcanoes during periods of relative quiescence (about $10 \mathrm{MW}$ ) and a value for the steam-heated Ketetahi Hot Springs area on Mt. Tongariro in New Zealand (36 MW). However, the total heat loss from the Lassen thermal areas is much larger than heat loss from the summit regions of other Cascade volcanoes. The greater heat loss at Lassen may reflect the presence of a larger, more silicic magmatic system. 


\section{REFERENCES CITED}

Beall, J.J., 1981, A hydrologic model based on deep test data from the Walker "O" No. 1 well, Terminal Geyser, California: Geothermal Resources Council Transactions, v. 5, p. 153-156.

Christopherson, K.R., and Pringle, Laurel, 1981, Additional audio-magnetotelluric soundings in the Lassen Known Geothermal Resources Area, Plumas and Tehama Counties, California: U.S. Geological Survey Open-File Report 81-959, 18 p.

Clynne, M.A., and Muffler, L.J.P., 1989, Lassen Volcanic National Park and vicinity, in South Cascades Arc Volcanism, California and Southern Oregon: Field Trip Guidebook T312, American Geophysical Union, Washington, D.C., p. T312:3-T312:15.

Dawson, G.B., 1964, The nature and assessment of heat flow from hydrothermal areas: New Zealand Journal of Geology and Geophysics, v. 7, p. 155-171.

Dawson, G.B., and Dickinson, D.J., 1970, Heat flow studies in thermal areas of North Island: United Nations Symposium on the Development and Utilization of Geothermal Resources, Pisa, Geothermics Special Issue 2, p. 466-473.

Day, A.L., and Allen, E.T., 1925, The volcanic activity and hot springs of Lassen Peak: Carnegie Institution of Washington, Washington, Publication No. 360, $190 \mathrm{p}$.

Fenneman, N.M., 1928, Physiographic division of the United States: U.S. Geological Survey (map), scale 1:7,000,000.

Frank, D.G., 1985, Hydrothermal processes at Mount Rainier, Washington: PhD Dissertation, University of Washington, Department of Geological Sciences, $196 \mathrm{p}$.

Friedman, J.D., and Frank, D., 1977, Heat discharge from Mount St. Helens, Washington: U.S. Geological Survey Open-File Report 77-541, 29 p.

Friedman, J.D., and Frank, D., 1978, Thermal surveillance of active volcanoes using Landsat-1 Data Collection System: Part 4, Lassen volcanic region: National Technical Information Services, NTIS N78 23499/LL, $46 \mathrm{p}$.

Friedman, J.D., and Frank, D., 1980, Infrared surveys, radiant flux, and total heat discharge at Mount Baker volcano, Washington, between 1970 and 1975: U.S. Geological Survey Professional Paper 1022-D, $33 \mathrm{p}$.

Friedman, J.D., Frank, D., and Kieffer, H.H., 1981, Thermal infrared surveys of the May 18 crater, subsequent lava domes, and associated volcanic deposits in Lipman, P.W., and Mullineaux, D.R. (eds), The 1980 eruptions of Mount St. Helens, Washington: U.S. Geological Survey Professional Paper 1250, p. 279-293.

Friedman, J.D., Williams, D.L., and Frank, D., 1982, Structural and heat-flow implications of infrared anomalies at Mount Hood, Oregon, 1972-1977: Journal of Geophysical Research, v. 87, no. B4, p. 2793-2803.

Giggenbach, W.F. and Stewart, M.K., 1982, Processes controlling the isotopic composition of steam and water discharges from steam vents and steam-heated pools in geothermal areas: Geothermics, v. 11, no. 2, p. 71-80.

Hochstein, M.A., and Bromley, C.J., 1979, Resistivity structure of the Tongariro thermal system, North Island, New Zealand: Proceedings of the 1st New Zealand Geothermal Workshop, p. 2028.

Hochstein, M.P., 1985, Steaming ground at Red Crater and in the Te Mari Craters, Mt. Tongariro Geothermal System (New Zealand): Proceedings of the 7th New Zealand Geothermal Workshop, p. 177-180.

Ingebritsen, S.E. and Sorey, M.L., 1985, A quantitative analysis of the Lassen hydrothermal system, north-central California: Water Resources Research, v. 21, p. 853-868. 
Ingebritsen, S.E., and Sorey, M.L., 1988, Vapor-dominated zones within hydrothermal systems: Evolution and natural state: Journal of Geophysical Research, v. 93, no. B11, p. 13,63513,655 .

Janik, C.J., Nehring, N.L., and Truesdell, A.H., 1983, Isotope geochemistry of thermal fluids from Lassen Volcanic National Park: Geothermal Resources Council Transactions, v. 7, p. 295-300.

Kieffer, H.H., Frank, D., and Friedman, J.D., 1981, Thermal infrared surveys at Mt. St. Helens observations prior to the eruption of May 18 in Lipman, P.W., and Mullineaux, D.R. (eds), The 1980 eruptions of Mount St. Helens, Washington: U.S. Geological Survey Professional Paper 1250 , p. 257-277.

Muffler, L.J.P., Nehring, N.L., Truesdell, A.H., Janik, C.J., Clynne, M.A., and Thompson, J.M., 1982, The Lassen geothermal system: Proceedings of Pacific Geothermal Conference 1982 incorporating the 4th New Zealand Geothermal Workshop, Auckland, New Zealand, p. 349356.

Muffler, L.J.P., Jordan, Raymond, and Cook, A.L., 1983, Maps showing thermal features and topography of Devils Kitchen and Bumpass Hell, Lassen Volcanic National Park, California: U.S. Geological Survey Miscellaneous Field Studies Map MF-1484, 1:2,000.

Paulson, K.M., and Ingebritsen, S.E., 1991, Sodium and chloride data from selected streams in the Lassen area, north-central California, and their relation to thermal-fluid discharge from the Lassen hydrothermal system: U.S. Geological Survey Water-Resources Investigation Report 90-4201, $29 \mathrm{p}$.

Sorey, M.L., 1986, Hot spring monitoring at Lassen Volcanic National Park, California 1983-85: Proceedings of the 11th Workshop on Geothermal Reservoir Engineering, Stanford University, p. 141-147.

Sorey, M.L., and Ingebritsen, S.E., 1984, Quantitative analysis of the hydrothermal system in Lassen Volcanic National Park and Lassen Known Geothermal Resource Area: U.S. Geological Survey Water Resources Investigations Report 84-4278, 80 p.

Sutton, O.G., 1953, Micrometeorology: McGraw-Hill, New York, 333 p.

Thompson, J.M., 1985, Chemistry of thermal and nonthermal springs in the vicinity of Lassen Volcanic National Park: Journal of Volcanology and Geothermal Research, v. 25, p. 81-104. Truesdell, A.H., Mazor, E., and Nehring, N.L., 1983, The origin of thermal fluids at Lassen Volcanic National Park: Evidence from noble and reactive gas abundances: Geothermal Resources Council Transactions, v. 7, p. 343-348.

Washburn, E.W., 1929, International Critical Tables of Numerical Data, Physics Chemistry \& Technology, v. 5, First Edition, McGraw-Hill, New York, 465 p.

White, D.E., Muffler, L.J.P., and Truesdell, A.H., 1971, Vapor-dominated hydrothermal systems compared with hot-water systems: Economic Geology, v. 66, p. 75-97. 